Sains Malaysiana 50(10)(2021): 3015-3033

http://doi.org/10.17576/jsm-2021-5010-15

\title{
Pichia-Expressed Recombinant D6 and DARC Negatively Affect Cell Migration and Invasion of Breast Cancer Cells
}

(Rekombinan D6 dan DARC Hasilan Pichia Mempengaruhi Migrasi Sel dan Serangan Sel Kanser Payudara secara Negatif)

\author{
TAN WeE Yee, Khoo Boon Yin \& CheW Ai LAN*
}

\begin{abstract}
Atypical chemokine receptor proteins are termed 'decoy proteins' as their binding to the respective ligands does not lead to a typical signaling pathway but intercepts the action of chemokines. This method of chemokine activity regulation may also function in tumor suppression. D6 and DARC (Duffy Antigen Receptor for Chemokines) have been reported as decoy chemokine receptors in cancer studies. Purified Pichia-expressed D6 and DARC, produced in-house, were used in cell-based studies to test their biological activities. Cell viability tests showed that recombinant D6 and DARC did not affect cell viability significantly, suggesting that they were not involved in breast cancer cell death. Wound healing assays showed that the presence of recombinant D6 or DARC at $10 \mu \mathrm{g} / \mathrm{mL}$ optimally inhibited the migration of breast cancer cells. ELISA showed an inverse relationship between the recombinant proteins and CCL levels in the treated cells. Migration assay using Boyden chamber demonstrated the function of the recombinant proteins in inhibiting chemotaxis activity of treated cells. Invasion assay showed the ability of the recombinant proteins in inhibiting the invasion property of treated cells. Comparison of single and combinatorial effects of the recombinant proteins showed that the combination of D6 and DARC at a $1: 1$ ratio $(10 \mu \mathrm{g} / \mathrm{mL})$ is most effective in reducing CCL levels and inhibiting the migration and invasion of treated cells. It was shown that the purified Pichia-expressed recombinant D6 and DARC are the negative regulators of breast cancer cell migration and invasion, and the inhibition effects were greater when they were used in combination.
\end{abstract}

Keywords: Breast cancer cells; CCL2; cell migration and invasion; D6; DARC

ABSTRAK

Protein reseptor kemokin atipikal disebut 'umpan protein' kerana pengikatannya dengan ligan masing-masing tidak membawa kepada jalan isyarat yang khas tetapi memintas tindakan kemokin. Ia merupakan satu kawalan aktiviti kemokin dan boleh berfungsi dalam penyekatan tumor. D6 dan DARC telah dilaporkan sebagai reseptor kemokin umpan dalam kajian kanser. D6 dan DARC ekspresi Pichia yang dihasilkan di makmal telah digunakan dalam kajian berdasarkan sel untuk menguji aktiviti biologinya. Ujian daya hidup sel menunjukkan bahawa rekombinan D6 dan DARC tidak mempengaruhi daya maju sel secara signifikan, menunjukkan bahawa mereka tidak terlibat dalam kematian sel barah payudara. Ujian penyembuhan luka menunjukkan bahawa kehadiran D6 atau DARC rekombinan pada $10 \mu \mathrm{g} / \mathrm{mL}$ menghalang penghijrahan sel barah payudara secara optimum. ELISA menunjukkan hubungan terbalik antara protein rekombinan dan tahap CCL pada sel yang dirawat. Ujian migrasi menggunakan ruang Boyden menunjukkan fungsi protein rekombinan dalam menghalang aktiviti kemotaksis sel yang dirawat. Ujian penaklukan menunjukkan kemampuan protein rekombinan dalam merencat sifat penaklukan sel yang dirawat. Membandingkan kesan tunggal dan gabungan protein rekombinan, gabungan D6 dan DARC pada nisbah 1: 1 (10 $\mu \mathrm{g} / \mathrm{mL})$ didapati paling baik dalam mengurangkan tahap CCL dan seterusnya menghalang migrasi dan penaklukan sel yang dirawat. Hasil kajian menunjukkan bahawa rekombinan D6 dan DARC hasilan Pichia bukan hanya pengawal negatif migrasi dan penaklukan sel barah payudara tetapi kesan perencatannya lebih besar ketika digunakan dalam gabungan.

Kata kunci: CCL2; D6; DARC; migrasi dan penaklukan sel; sel payudara

\section{INTRODUCTION}

Breast cancer has been one of the most commonly occurring cancers in the world in recent years, with over two million new cases and 600,000 deaths in 2018 alone
(Bray et al. 2018). In oncology study, breast cancer research had become one of the most progressively evolving fields. To date, with the advanced understanding of the key molecular features, breast cancer is no longer 
considered a single disease but a combination of different subtypes with different biological behaviors and clinical outcomes (Sandhu et al. 2010). Novel molecules and new diagnostic methods are being discovered and developed globally. Recently, the identification of the various signaling pathways implicated in the cellular processes of breast cancer cells has drawn the attention of researchers worldwide. The involvement of growth factors or signaling molecules in breast cancer cell proliferation and invasion has also been reported (Ahmad et al. 2011; Cabioglu et al. 2009).

The expression of chemokine receptors has been found to be restricted and specific in many cancer cells. Besides aiding in cell growth and survival, chemokine receptors also facilitate the characteristic patterns of metastasis (Slettenaar \& Wilson 2006). Recently, many studies have reported findings on the atypical action of chemokine receptor proteins. These receptor proteins were termed 'decoy proteins' or 'scavenger proteins' since the binding of these proteins to their respective ligands does not lead to the typical signaling pathway but intercepts the respective pathway and neutralizes the action of chemokines. Hence, they are well-known as 'intercepting receptors', the decoy chemokine receptors that confiscate chemokines without activating the respective signaling pathway (Hansell et al. 2006; Wang et al. 2006; Wu et al. 2008). The binding of chemokines without triggering the G-protein signaling pathway is a way of regulating chemokine activity and may function as a tumor suppressor (Graham 2009). It has emerged as a general strategy in recent years to tune the actions of cytokines and growth factors.

To date, six types of atypical chemokine receptors (ACKR) have been reported and categorized, namely ACKR1 (formerly known as DARC), ACKR2 (also known as D6 or Chemokine-binding protein 2, CCBP2), ACKR3 (Cysteine-X-cysteine chemokine receptor 7, CXCR7 or RDC1), ACKR4 (C-C chemokine receptor 1, CCRL1), ACKR5 (CCRL2), and ACKR6 (Phosphatidylinositol transfer protein 3, PITPNM3 or Nir1) (Lokeshwar et al. 2020). Although chemokine decoy receptors differ from antibodies and small molecule receptor antagonists, they generally have broad specificity of ligands that are recognized by different receptors (Mantovani et al. 2006). For examples, DARC (currently known as ACKR1) binds angiogenic chemokines (Maryam et al. 2020) and was suggested to play a vital role in leukocyte recruitment in inflammatory diseases (Gencer et al. 2019), whereas D6 (ACKR2) is an atypical chemokine receptor with a non-redundant role in controlling inflammation and immunity by scavenging inflammatory chemokines (Saçmacı \& Özcan 2020; Vacchini et al. 2020; Wilson et al.
2020). A single use of chemokine decoy receptor proteins, such as D6 or DARC, has been shown to neutralize the action of CCL2 in vitro (Wang et al. 2006; Wu et al. 2008). However, a combinatorial effect of D6 and DARC in invasive breast cancer cells and their effects on cell invasion and migration is yet to be explored. Thus, in this study, two types of decoy chemokine receptor proteins, Pichia-expressed recombinant D6 and DARC produced in-house, were introduced to the breast cancer cells, namely MDA-MB-231 and MCF-7. The effects of recombinant D6 and DARC on cell migration and invasion were investigated. They were used individually as well as in combination.

\section{Materials AND METHODS}

\section{CELL CULTURE AND REAGENTS}

Invasive breast cancer cell line MDA-MB-231 (ATCC number: HTB-26) and non-invasive breast cancer cell line MCF-7 (ATCC number: HTB-22) were obtained from the American Type Culture Collection (ATCC; Manassas, USA). Both MDA-MB-231 and MCF-7 cells were cultured in Dulbecco's Modified Eagle's Medium (DMEM) supplemented with 10\% heat inactivated fetal bovine serum (FBS), $100 \mathrm{U} / \mathrm{mL}$ of penicillin, and $100 \mu \mathrm{g} /$ $\mathrm{mL}$ of streptomycin. Cells were maintained at $37{ }^{\circ} \mathrm{C}$ in a humidity-controlled incubator with $5 \% \mathrm{CO}_{2}$.

\section{MTT ASSAY}

The MTT (3-[4,5-dimethylthiazole-2-yl]-2,5diphenyltetrazolium bromide) assay was carried out to determine the effects of recombinant D6 and DARC on the viability of MDA-MB-231 and MCF-7 cells, respectively. Both the cells were individually seeded in 96-well plates at a density of $1 \times 10^{4}$ cells per well and cultured at $37{ }^{\circ} \mathrm{C}$ in a humidity-controlled incubator with $5 \% \mathrm{CO}_{2}$. After $24 \mathrm{~h}$ of incubation, different concentrations of recombinant D6 and DARC $(2,6,10,20,50$, and 100 $\mu \mathrm{g} / \mathrm{mL}$ ) were introduced to the cells. Negative control wells of MDA-MB-231 and MCF-7 cells were treated with $0.5 \%(\mathrm{v} / \mathrm{v})$ of dimethyl sulfoxide (DMSO). After $24 \mathrm{~h}$ of treatment, $20 \mu \mathrm{L}$ of MTT solution $(5 \mathrm{mg} / \mathrm{mL}$ in PBS) was added to each of the wells, and the plates were incubated at $37^{\circ} \mathrm{C}$ in a $\mathrm{CO}_{2}$ incubator for $4 \mathrm{~h}$. Following removal of the medium, $100 \mu \mathrm{L}$ of DMSO was added to each well, and the absorbance intensity was measured at $570 \mathrm{~nm}(650$ $\mathrm{nm}$ as the reference or background wavelength) using a microplate reader. All MTT assays were performed in triplicates, and the results were expressed as a percentage of treated viable cells relative to untreated viable cells. 


\section{WOUND HEALING ASSAY}

Wound healing assay was performed on $100 \%$ confluent cells in 24-well plates. Approximately $2 \times 10^{5}$ cells were seeded with fresh DMEM and incubated overnight at $37{ }^{\circ} \mathrm{C}$ in a $5 \%$ humidified $\mathrm{CO}_{2}$ incubator. A sterile 10 $\mu \mathrm{L}$ micropipette tip was used to scratch the confluent cell monolayer to create a wound or cell-free gap approximately $1 \mathrm{~mm}$ wide. The cells were then rinsed with sterile phosphate buffer saline (PBS) pH 7.2 to remove detached cells and cell debris. Next, the cells were treated with different concentrations $(2 \mu \mathrm{g} / \mathrm{mL}, 6 \mu \mathrm{g} /$ $\mathrm{mL}$, and $10 \mu \mathrm{g} / \mathrm{mL}$ ) of recombinant D6 or DARC. The plate was finally incubated at $37^{\circ} \mathrm{C}$ in a $\mathrm{CO}_{2}$ incubator and monitored under a phase contrast microscope after $0,6,24$, and $30 \mathrm{~h}$. Images of cells were captured, and the wound gap of cells was analyzed using Image J 1.51p. Two-way ANOVA was performed to further analyze the data statistically.

\section{DETERMINATION OF CCL2 EXPRESSION LEVEL WITH} ELISA

Approximately $2 \times 10^{5}$ cells were seeded in 24-well plates with fresh DMEM and incubated overnight at $37{ }^{\circ} \mathrm{C}$ in a $5 \%$ humidified $\mathrm{CO}_{2}$ incubator. Cells achieving $100 \%$ confluence were then treated with different concentrations $(2 \mu \mathrm{g} / \mathrm{mL}, 6 \mu \mathrm{g} / \mathrm{mL}$, and $10 \mu \mathrm{g} /$ $\mathrm{mL}$ ) of recombinant D6 or DARC. Negative control was cells without any treatment but added only with fresh DMEM. After $24 \mathrm{~h}$ of incubation, the cells were rinsed twice with sterile PBS pH 7.2. Then, $100 \mu \mathrm{L}$ of M-PER reagent was added to each well and incubated at $37{ }^{\circ} \mathrm{C}$ in a $\mathrm{CO}_{2}$ incubator for $10 \mathrm{~min}$. The content of each well was centrifuged at $600 \times \mathrm{g}$ for $2 \mathrm{~min}$, and the supernatant was collected for enzyme-linked immunosorbent assay (ELISA). For indirect ELISA, the 96-well plate was coated with the sample and incubated overnight at $4{ }^{\circ} \mathrm{C}$. The plate was washed with PBS pH 7.2 and then blocked with $3 \%$ bovine serum albumin solution, with agitation at $300 \mathrm{rpm}$ for an hour at $37^{\circ} \mathrm{C}$. Then, the plate was washed, and the primary antibody anti-CCL2 was added to the sample wells, followed by agitation at $300 \mathrm{rpm}$ for $2 \mathrm{~h}$ at $37{ }^{\circ} \mathrm{C}$. After washing, anti-IgG (secondary antibody) was added, and the plate was incubated for $1 \mathrm{~h}$. Then, the plate was washed, TMB (3,3',5,5'-Tertramethylbenzidine) solution added, and the plate incubated for $30 \mathrm{~min}$. The reaction was stopped by adding $100 \mu \mathrm{L}$ of $1 \mathrm{M} \mathrm{H}_{3} \mathrm{PO}_{4}$, and the plate was read at $450 \mathrm{~nm}$ using a microplate reader.

\section{MIGRATION ASSAY}

Boyden chamber system (24 wells, transparent PET membrane of $8 \mu \mathrm{m}$ pore size; Corning, United States) was used to perform the migration assay. Upon attaining 70\% confluency, the cells were trypsinized and resuspended in serum-free DMEM containing different concentrations $(2 \mu \mathrm{g} / \mathrm{mL}, 6 \mu \mathrm{g} / \mathrm{mL}$, and $10 \mu \mathrm{g} / \mathrm{mL}$ ) of recombinant D6 or DARC or a combination of both in different ratios. The cell suspension was added into each insert at a density of 2 $\times 10^{5}$ of cells per well. A $10 \%$ FBS-containing medium was then added to the lower chamber that served as a chemoattractant. The cells in the 24-well migration plate were allowed $24 \mathrm{~h}$ to migrate across the $8 \mu \mathrm{m}$ polycarbonate membrane, and then, the cells were fixed in $100 \%$ methanol (Fisher Scientific, United States) for $20 \mathrm{~min}$. Methanol was then removed, and the insert was rinsed with PBS pH 7.2 before the membranes and cells were stained with $0.25 \%$ crystal violet (Sigma-Aldrich, United States) for $15 \mathrm{~min}$. The inserts were rinsed twice with sterile PBS. The non-migratory cells remaining in the upper chamber were removed using a sterile cotton swab. Inserts were air-dried, observed under a phase contrast microscope, and images were photographed in randomly selected fields of view at $400 \times$ magnification. Finally, the bottom parts of the inserts were soaked in glacial acetic acid for $10 \mathrm{~min}$ at room temperature with intermittent gentle shaking to lyse the invaded cells and elute the crystal violet dye. The stained glacial acetic acid was then transferred to a 96-well plate, and $\mathrm{OD}_{570}$ was read using a microplate reader.

\section{INVASION ASSAY}

Corning ${ }^{\circledR}$ BioCoat ${ }^{\mathrm{TM}}$ Matrigel ${ }^{\circledR}$ Invasion Chambers (Corning, United States) with 24 wells was used for the invasion assay along with 12 inserts. Prior to use, the invasion plate was rehydrated with serum-free DMEM at $37{ }^{\circ} \mathrm{C}$ in a $5 \%$ humidified $\mathrm{CO}_{2}$ incubator for $2 \mathrm{~h}$. For invasion assays, cells were grown and treated as described in the migration assay section. An equal number of cells $\left(1 \times 10^{5}\right.$ cells $)$ in $300 \mu \mathrm{L}$ serum-free DMEM were loaded into the Matrigel precoated chambers. Then, $600 \mu \mathrm{L}$ of DMEM supplemented with $10 \%$ FBS was placed in the lower compartment of the chamber as the chemoattractant. After allowing $24 \mathrm{~h}$ for invasion, cells were fixed, stained with $0.25 \%$ crystal violet, and quantified as previously described after the non-invading cells were removed with cotton swabs.

\section{STATISTICAL ANALYSIS}

All statistical analyses were performed using Statistical Package for the Social Sciences (SPSS) 13.0 (SPSS Inc., USA) statistical software and GraphPad Prism 7.0 (GraphPad, USA). The statistical significance was analyzed by one-way ANOVA with post hoc Duncan test with only one independent variable in the respective 
experiments. On the other hand, two-way ANOVA with Tukey post hoc test was performed to analyze the result of the experiments with two independent variables. Experiments were performed in triplicates, and data were reported as the mean \pm standard deviation (SD). Statistical significance was determined at a probability value of $<0.05$. Means with different letters represent a significant difference $(p<0.05)$. Standard deviation was calculated and presented as an error bar on graphs.

\section{RESULTS}

MTT ASSAY

The cytotoxic effect of the purified yeast-expressed recombinant D6 and DARC on MDA-MB-231 and MCF7 cancer cells was investigated to determine the noncytotoxic concentration of the recombinant proteins for further experiments. Figure 1(a) showed that after $24 \mathrm{~h}$ of treatment with varying concentrations of recombinant D6, ranging from $2 \mu \mathrm{g} / \mathrm{mL}$ to $100 \mu \mathrm{g} / \mathrm{mL}$, the viability of MDA-MB-231 and MCF-7 cells was not significantly affected compared to the non-treated cells. Similarly, Figure 1(b) illustrated that recombinant DARC did not affect the cell viability of MDA-MB-231 and MCF-7 cells. The viability of both cancer cell lines was observed to remain above $50 \%$ even after treatment with $100 \mu \mathrm{g} /$ $\mathrm{mL}$ of recombinant DARC protein.

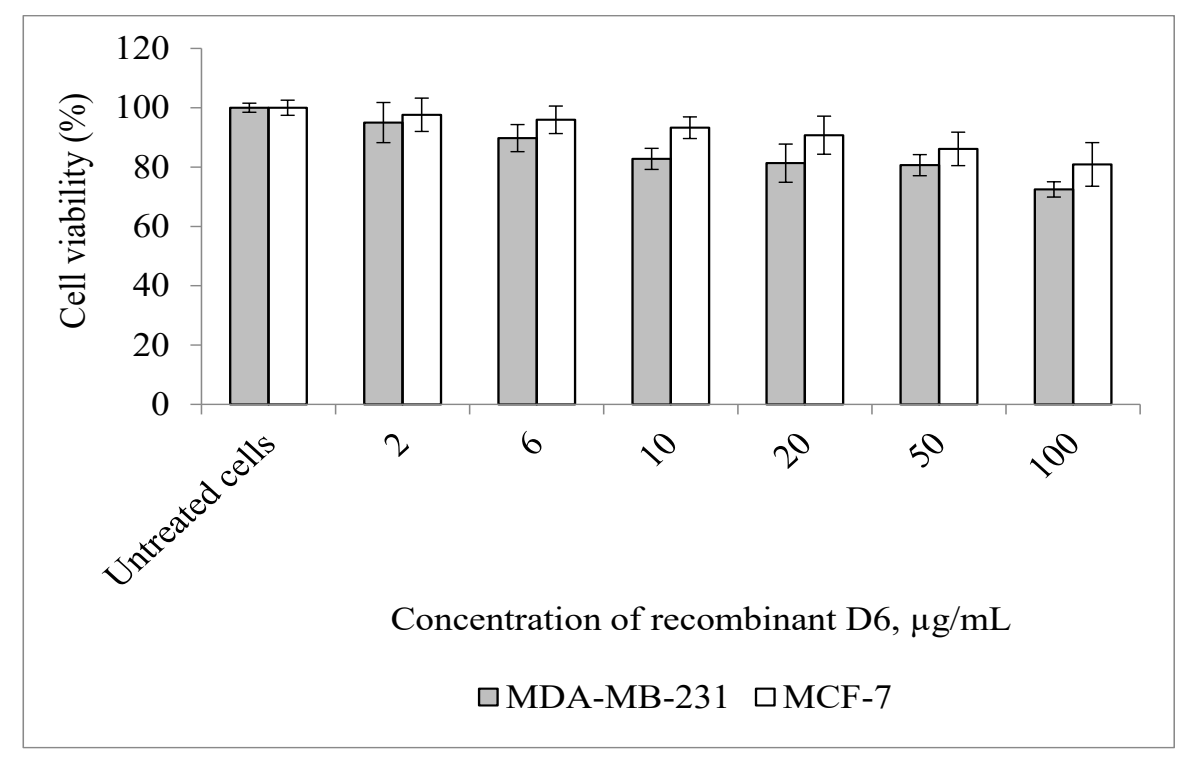

FIGURE 1(a). Effect of purified recombinant D6 on the viability of selected breast cancer cell lines after $24 \mathrm{~h}$ of treatment

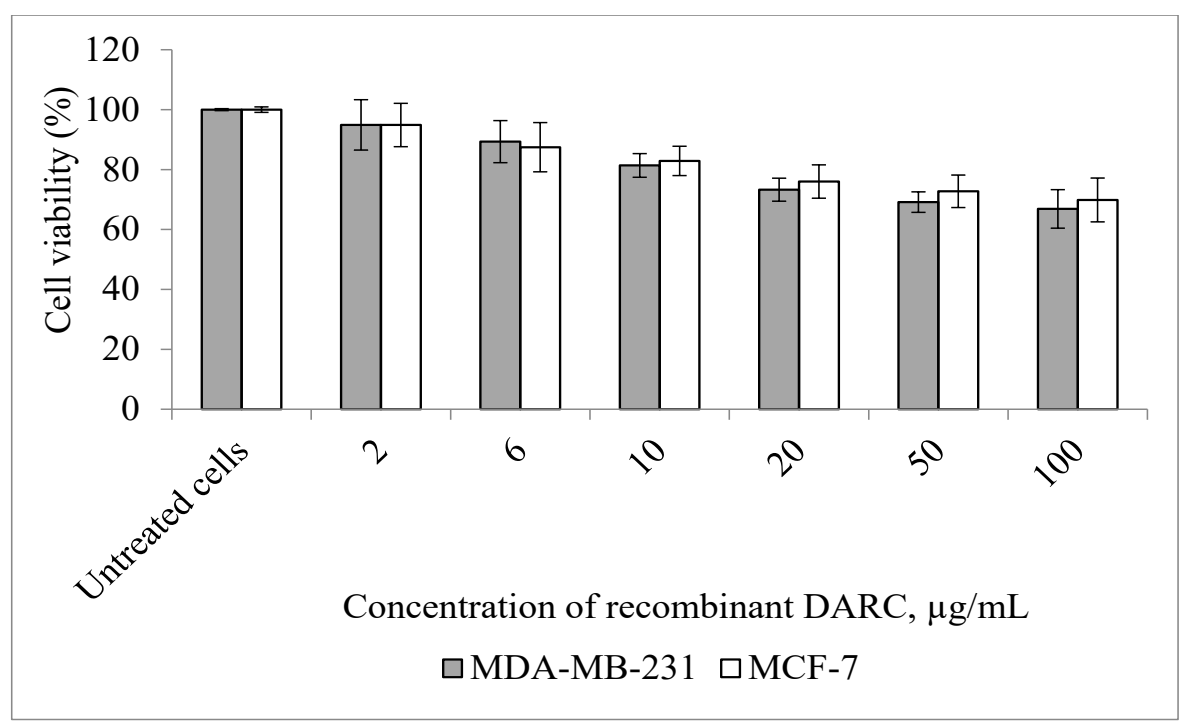

FIGURE 1(b). Effect of purified recombinant DARC on the viability of selected breast cancer cell lines after $24 \mathrm{~h}$ of treatment 


\section{WOUND HEALING ASSAY}

The effects of recombinant D6 and DARC proteins on cell migration were first evaluated qualitatively by wound healing assay. In wound healing assay, cell migration, or in other words the movement of cells into the wound area, was an indication of wound recovery. The wound gaps were observed after $6 \mathrm{~h}, 24 \mathrm{~h}$, and $30 \mathrm{~h}$ posttreatment with selected recombinant proteins at fixed concentrations (Table 1). The area of the wound measured at indicated time points using Image J was compared with the untreated cells (Negative Control). Mean values of triplicates (three measurements on the wound) were presented, and standard deviations were reported as error bars in bar charts. Two-way ANOVA was performed to analyze the results. In this study, the concentration of recombinant proteins and incubation times are the two independent variables. A $p$ value of $<0.05$ was considered statistically significant.

Figure 2(a) and Figure 2(b) showed the effects of recombinant D6 and DARC proteins on the migration of non-invasive MCF-7 cells, as assessed by wound healing assay. The untreated cells (Negative Control) healed after $30 \mathrm{~h}$ of incubation. Wound area for cells treated with $2 \mu \mathrm{g} / \mathrm{mL}, 6 \mu \mathrm{g} / \mathrm{mL}$, and $10 \mu \mathrm{g} / \mathrm{mL}$ of recombinant D6 reduced in a time-dependent manner. Moreover, at every indicated time point ( $6 \mathrm{~h}, 24 \mathrm{~h}$, and $30 \mathrm{~h}$ post-treatment), the wound gap of the treated cells was observed to reduce with the reduction of recombinant D6 dosage. The lower the dosage, the smaller the wound gap.

TABLE 1. Wound gaps observed at indicated time points after treatment with recombinant proteins

Incubation time (h)

0

6

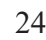

30
MDA-MB-231 cells
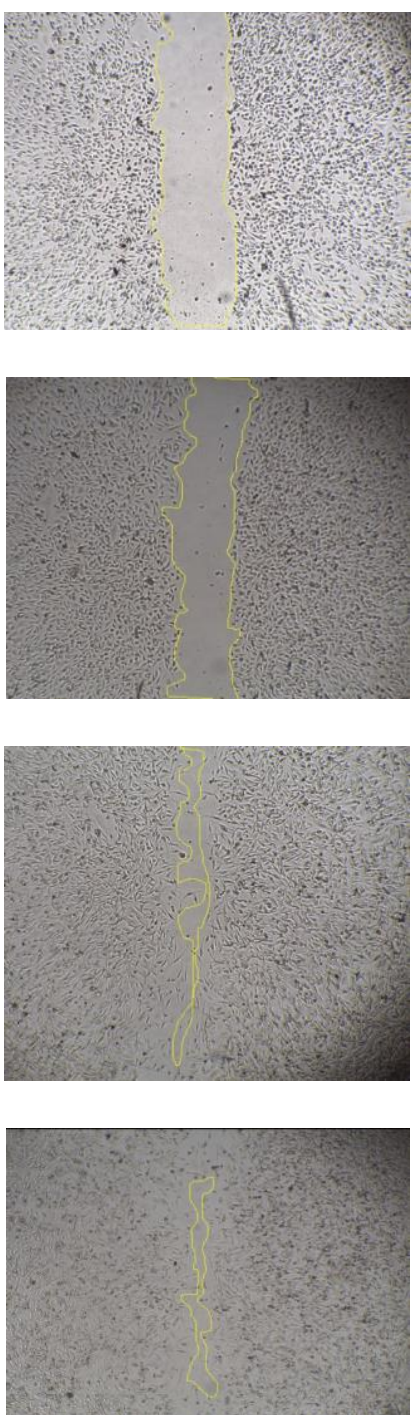
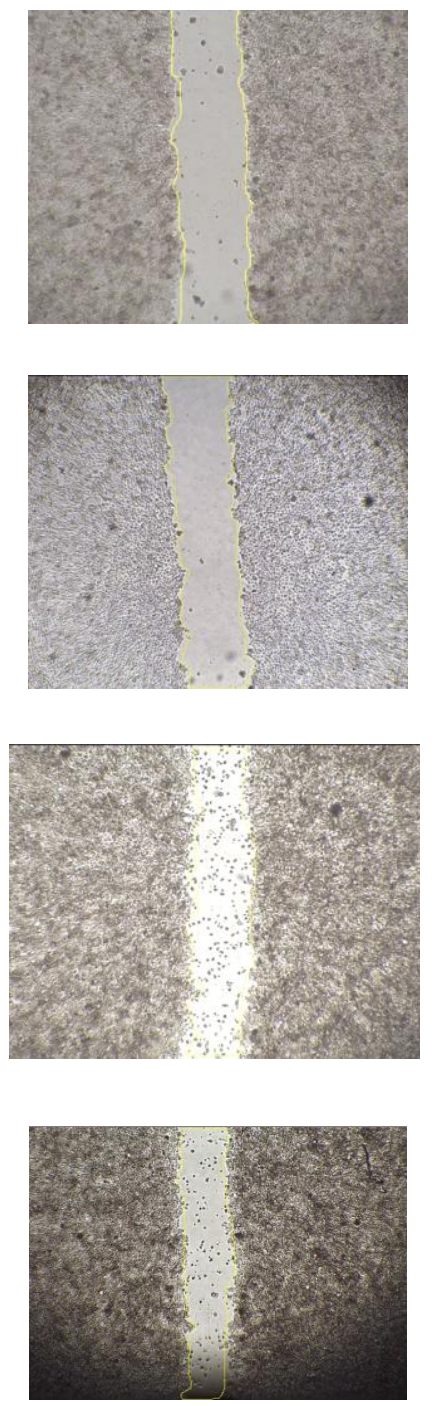


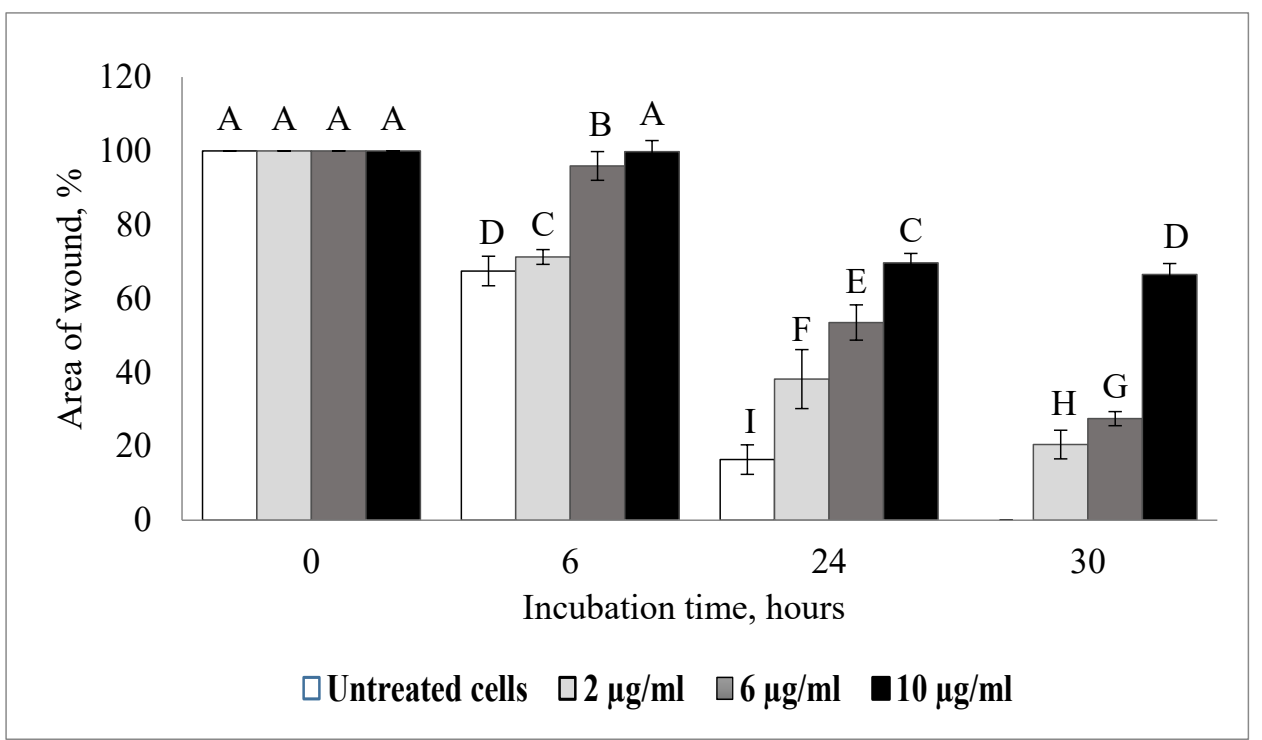

FIGURE 2(a). Effect of recombinant D6 on the migration of MCF-7 cells in wound healing assay

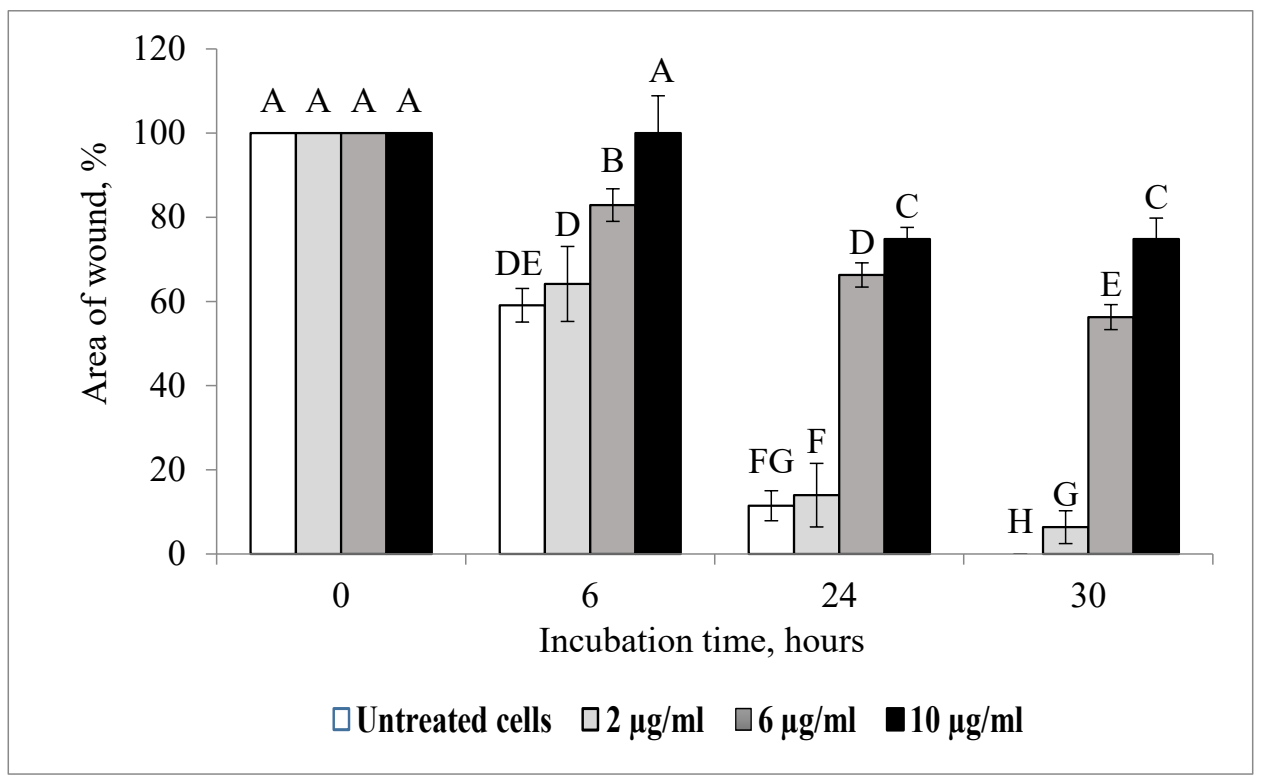

FIGURE 2(b). Effect of recombinant DARC on the migration of MCF-7 cells in wound healing assay

Figure 2(c) and Figure 2(d) showed the results of wound healing assays on MDA-MB-231 cells treated with recombinant D6 and DARC. As observed in Figure 2(c), no wound gap was seen on cells treated with $2 \mu \mathrm{g} / \mathrm{mL}$ and 6 $\mu \mathrm{g} / \mathrm{mL}$ of recombinant $\mathrm{D} 6$ at $24 \mathrm{~h}$ of post-treatment. The result was the same with the Negative Control, the cells which were not treated with recombinant D6. When treated with $10 \mu \mathrm{g} / \mathrm{mL}$ of recombinant $\mathrm{D} 6$, the wound gap reduced as incubation time increased from $6 \mathrm{~h}$ to $24 \mathrm{~h}$, and no wound gap was observed at $30 \mathrm{~h}$ post-treatment. Figure 2(d) reflected the effects of recombinant DARC at various concentrations on cell migration in MDA-MB-231 
cells. Non-treated cells showed an aggressive movement of cells, as observed at $6 \mathrm{~h}, 24 \mathrm{~h}$, and $30 \mathrm{~h}$. The wound area of the non-treated cells was $<50 \%$ at $6 \mathrm{~h}$ compared to $0 \mathrm{~h}$. At $24 \mathrm{~h}$, the wound gap was filled with migrated cells. For treatment with recombinant DARC at concentrations of $2 \mu \mathrm{g} / \mathrm{mL}$ and $6 \mu \mathrm{g} / \mathrm{mL}$, the rate of migration was reduced compared to non-treated cells. At $6 \mathrm{~h}$ post-treatment, wound gaps of treated cells were larger compared to nontreated cells. However, the wound gap was observed to be filled at $24 \mathrm{~h}$ post-treatment. For cells treated with 10 $\mu \mathrm{g} / \mathrm{mL}$ of recombinant DARC, the wound gap remained above $50 \%$ at $6 \mathrm{~h}$ post-incubation compared to $0 \mathrm{~h}$. At 24 and $30 \mathrm{~h}$, the wound areas remained visible, but the width of the wound gap was observed to be narrower with increased incubation time.

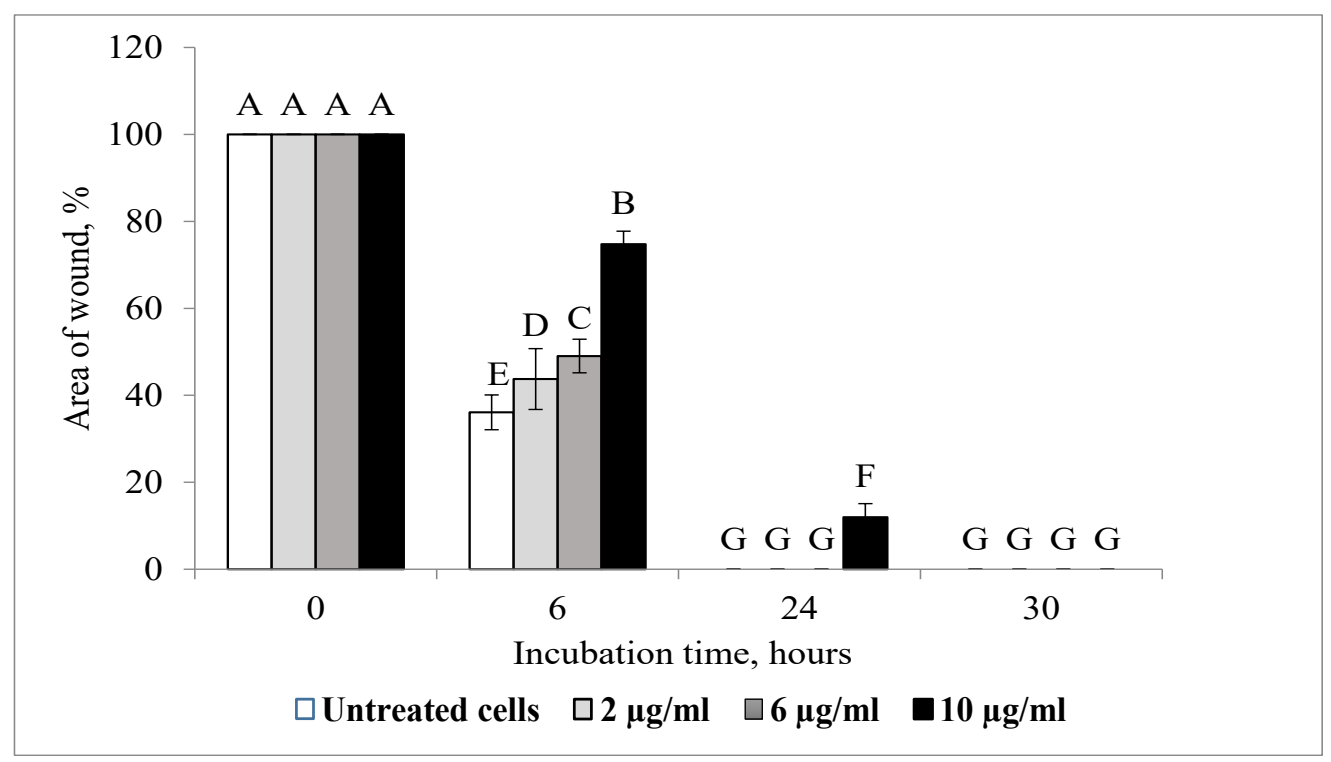

FIGURE 2(c). Effect of recombinant D6 on the migration of MDA-MB-231 cells in wound healing assay

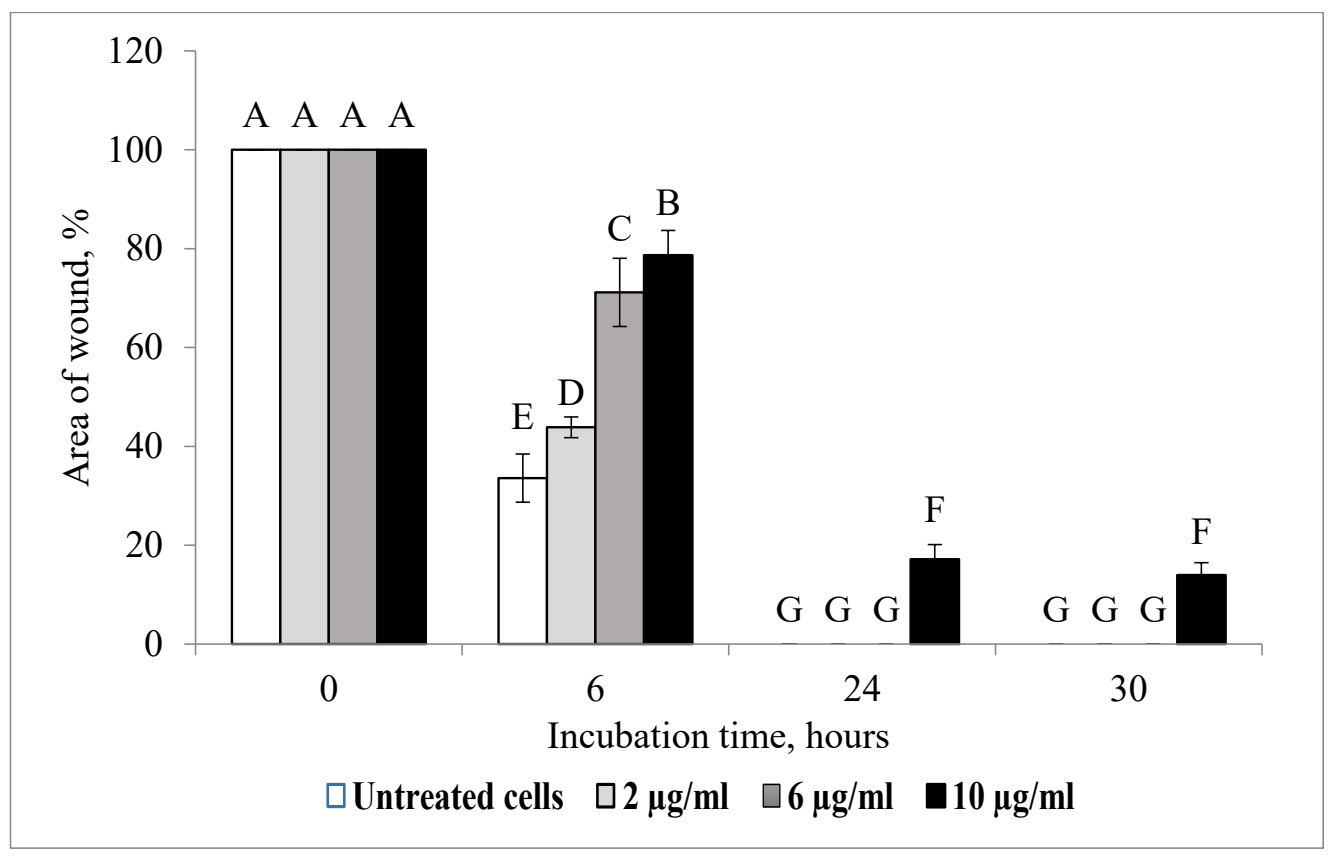

FIGURE 2(d). Effect of recombinant DARC on the migration of MDA-MB-231 cells in wound healing assay 
After studying the individual effects of recombinant D6 and DARC on cell migration, the combinatory effect of recombinant D6 and DARC was evaluated by wound healing assay on MDA-MB-231 cells with MCF-7 cells as a background control. Recombinant D6 and DARC were combined at three different ratios, as illustrated in Figure 2(e). At $24 \mathrm{~h}$ post-treatment, non-treated MDAMB-231 cells healed, while non-treated MCF-7 cells were observed to have a wound area as small as $16.10 \%$ compared to $0 \mathrm{~h}$. Among the three different ratios of combinations, the wound gap of MDA-MB-231 treated with recombinant D6 and DARC at the ratio of $1: 1$ was observed to be the largest $(16.99 \%$ compared to 0 h), followed by ratio of $2: 1$ and $1: 2$. However, every treatment group of MCF-7 cells was observed to have wound areas above $50 \%$ after $24 \mathrm{~h}$ post-treatment. Results showed that the combination of recombinant D6 and DARC at a ratio of 1:1 was the best among the three tested combination ratios.

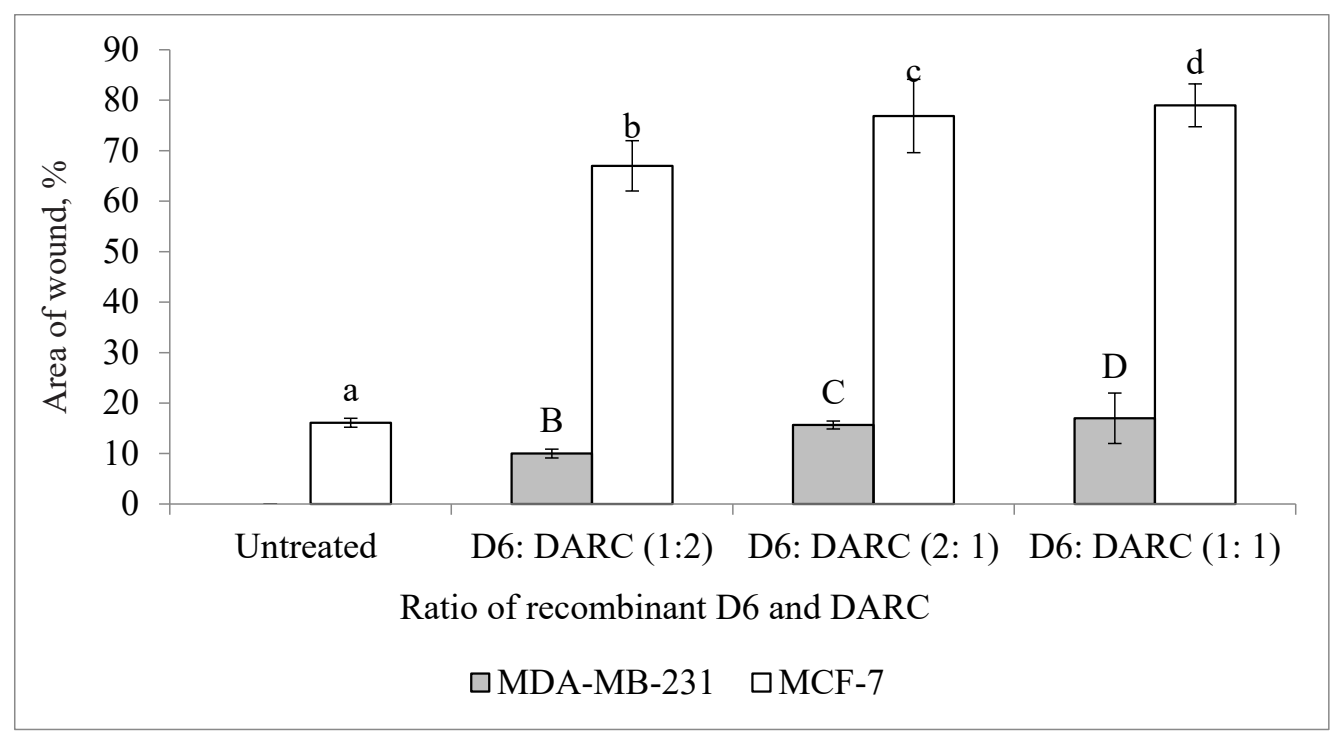

FIGURE 2(e). Effect of combination of recombinant D6 and DARC on the migration of MDA-MB-231 and MCF-7 cells in wound healing assay

\section{DETERMINATION OF CCL2 EXPRESSION LEVEL WITH ELISA}

In addition to wound healing assay, determination of CCL2 level was performed through ELISA to further justify the effects of recombinant D6 and DARC on cell migration. Figure 3(a) showed that the amount of CCL2 detected from MDA-MB-231 cells and MCF-7 cells decreased with the increased dosage of recombinant D6. The lowest CCL2 level was detected from cells (MDA-MB-231 and MCF-7) treated with $10 \mu \mathrm{g} / \mathrm{mL}$ of recombinant D6. Approximately $48.96 \%$ of CCL2 was obtained from MDA-MB-231 cells and $76.16 \%$ from MCF-7 cells after $24 \mathrm{~h}$ of treatment.

As shown in Figure 3(b), cells treated with recombinant DARC showed similar trends as the cells treated with recombinant D6. As the dosage of recombinant DARC increased, the amount of CCL2 obtained from MDA-MB-231 or MCF-7 cells decreased. Cells treated with $10 \mu \mathrm{g} / \mathrm{mL}$ of recombinant DARC expressed the lowest CCL2 level of $57.67 \%$ in MDAMB-231 and 71.38\% in MCF-7. In Figure 3(c), among the three different combination ratios of recombinant D6 and DARC, the lowest level of CCL2 was detected in MDA-MB-231 cells $(55.99 \%)$ treated at the ratio of $1: 1$, followed by ratio $2: 1$ and 1:2. However, for MCF-7 cells, the lowest CCL2 level was detected for ratio 1:2 $(40.76 \%)$.

\section{MIGRATION ASSAYS}

Migration assay was conducted using the Boyden chamber to quantitatively justify the effects of recombinant D6 and DARC on cell migration. A phase contrast microscope was used to capture images of the 
cells that have migrated across the membrane barrier of the Boyden chamber at the studied time points. The migration ability of treated and non-treated cells was determined through absorbance measurement by a microplate reader. Figure 4(a) demonstrated the cell migration of treated and untreated cells after $24 \mathrm{~h}$ of treatment. Images of non-treated cells showed plenty of cells at the bottom of the Boyden chamber as untreated cells exhibited an aggressive phenotype and metastasized across the membrane barrier. On the other hand, treated cells were observed to show reduced migration ability after $24 \mathrm{~h}$ of treatment, and lesser cells were seen at the bottom of the Boyden chamber under the phase contrast microscope.

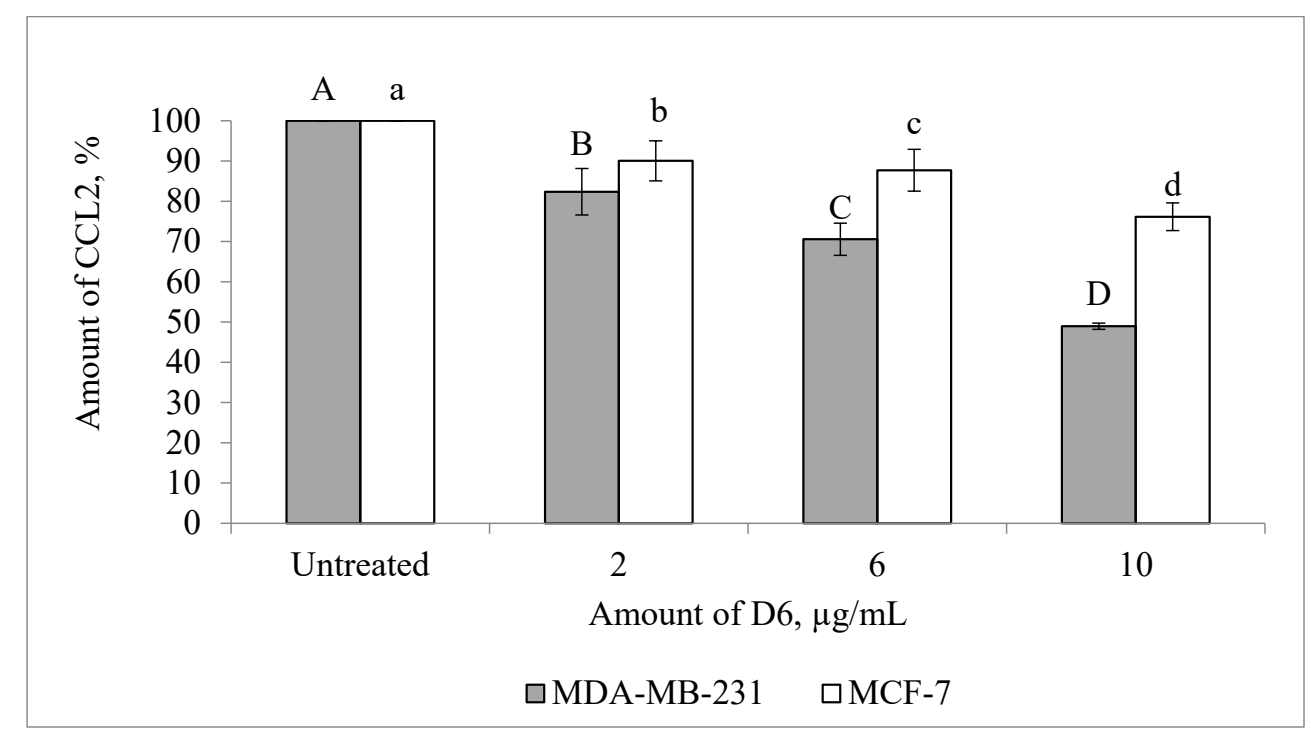

FIGURE 3(a). Effect of recombinant D6 on CCL2 expression level in MDA-

MB-231 and MCF-7 cells

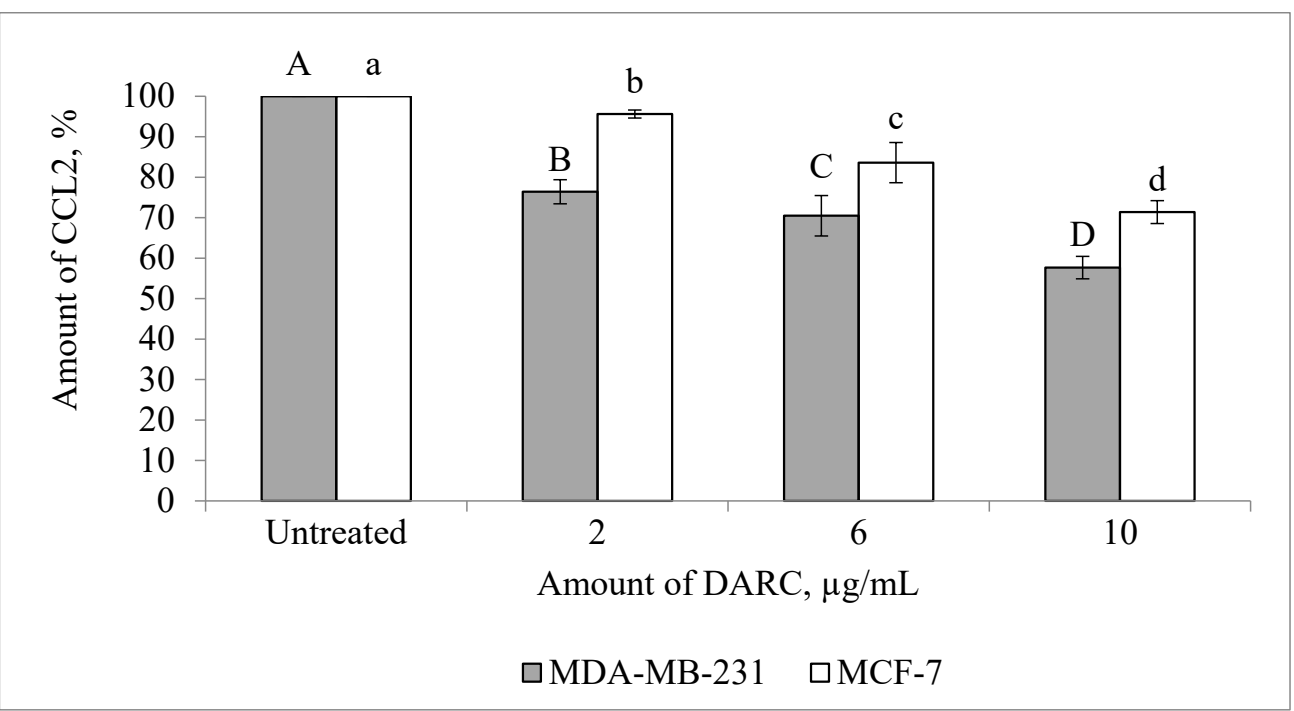

FIGURE 3(b). Effect of recombinant DARC on CCL2 expression level in MDAMB-231 and MCF-7 cells 


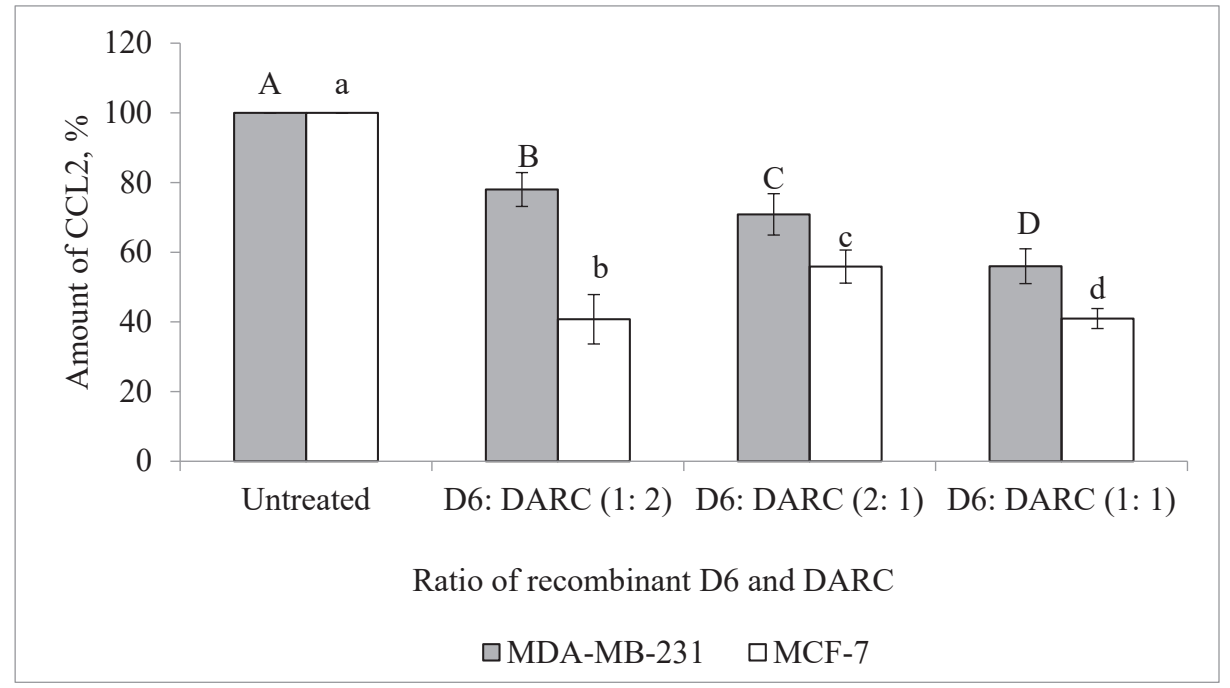

The experiments were carried out in triplicates and means with a significant difference are represented with different letters (Duncan, $p$ $<0.05$ ). Capital letters indicate the means for the amount of CCL2 from MDA-MB-231, whereas small letters indicate the means for the amount ofCCL2 from MCF-7. Error bars indicate the standard deviation values of the triplicatesInvading cells are indicated by arrows

FIGURE 3(c). Effect of combination of recombinant D6 and DARC on CCL2 expression level in MDA-MB-231 and MCF-7 cells

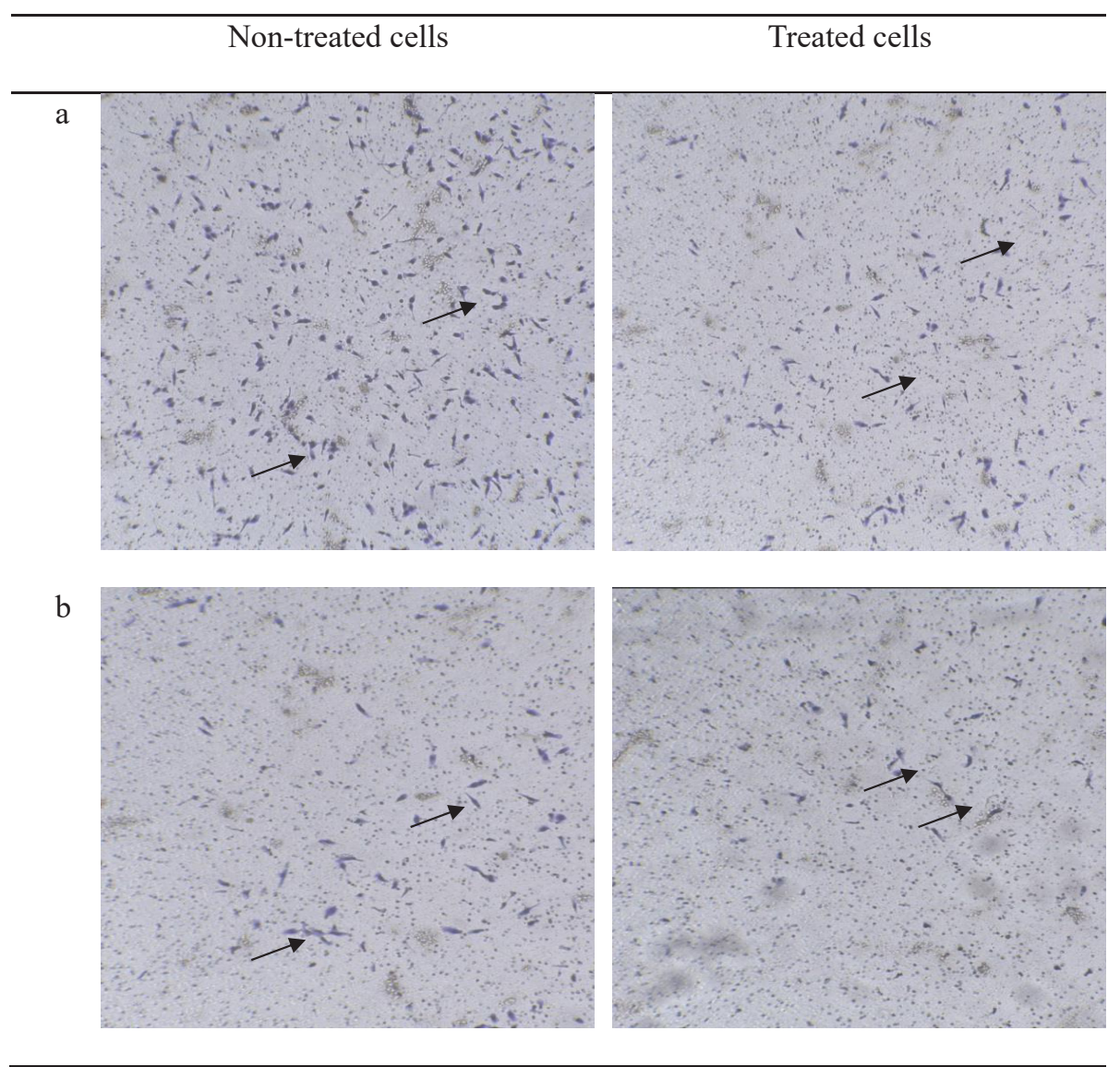

FIGURE 4(a). Cell migration images of (a) MDA-MB-231 \& (b) MCF-7 under phase contrast microscope $(400 \times$ magnification). Invading cells are indicated by arrows 
The migration abilities of MDA-MB-231 and MCF7 cells were shown to be affected by treatment with recombinant D6. Figure 4(b) showed that the number of migrated cells was negatively correlated with the concentration of recombinant D6. As the dosage of recombinant D6 increased in the cell medium, the migration ability of cells reduced. The least number of migrated cells was observed after treatment with $10 \mu \mathrm{g} / \mathrm{mL}$ of recombinant D6 (MDA-MB-231 cells: 65.97\%; MCF-7 cells: 39.88\%). Similar results were obtained after the treatment with recombinant DARC. Figure 4(c) depicted that the higher the concentration of recombinant DARC introduced to the cell medium, the lower the number of migrated cells detected at the bottom of the Boyden chamber. The lowest number of migrated cells was detected after treatment with $10 \mu \mathrm{g} /$ $\mathrm{mL}$ of recombinant DARC, with around $60.77 \%$ for MDA-MB-231 and 29.09\% for MCF-7. Figure 4(d) showed that the combination of recombinant D6 and DARC at the ratio of 1:1 showed the highest reduction effect on the migration of MDA-MB-231 and MCF-7 cells. The number of migrated cells treated with recombinant D6 and DARC at the ratio of 1:1 was significantly lower than untreated cells (Duncan, $p<0.05$ ).

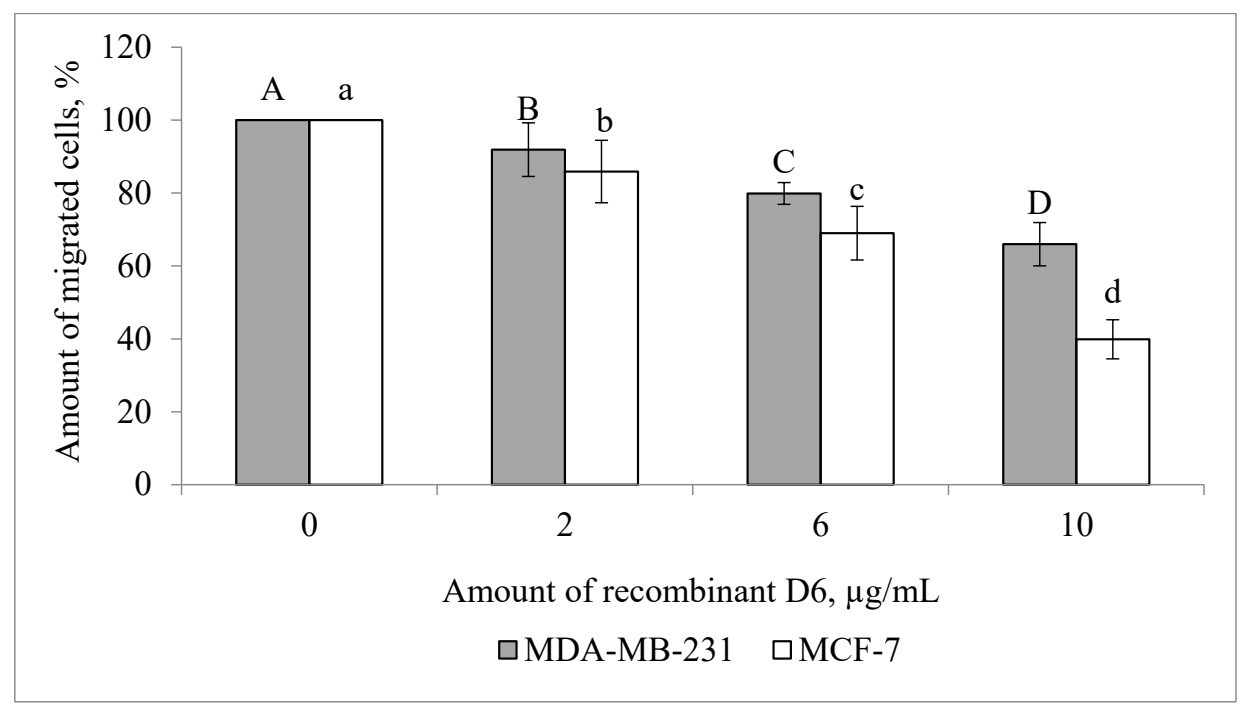

FIGURE 4(b). Effect of recombinant D6 on the migration of MDA-MB-231 and MCF-7 cells via Boyden chamber assay

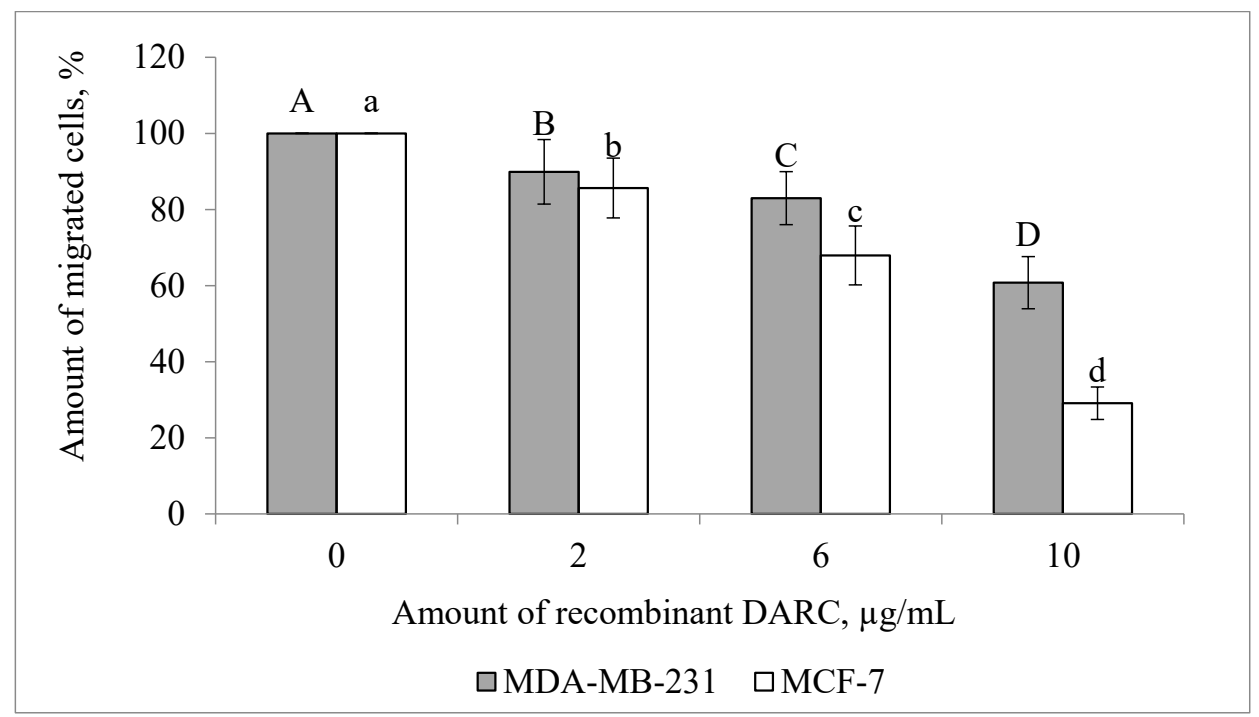

FIGURE 4(c). Effect of recombinant DARC on the migration of MDA-MB-231 and MCF-7 cells via Boyden chamber assay 


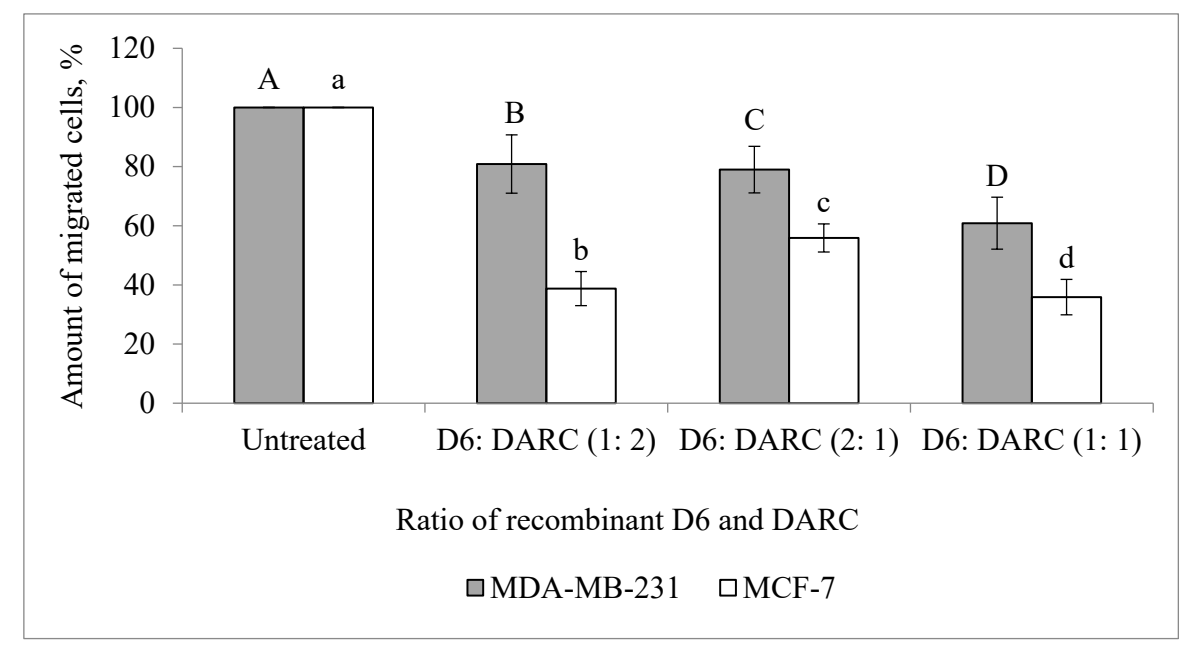

The experiments were carried out in triplicates and means with a significant difference are represented with different letters (Duncan, $p<0.05$ ). Capital letters indicate the means for the number of migrated cells from MDA-MB-231, whereas small letters indicate the means for the number of migrated cells from MCF-7. Error bars indicate the standard deviation values of the triplicates

FIGURE 4(d). Effect of combination of recombinant D6 and DARC on the migration of MDA-MB-231 and MCF-7 cells via Boyden chamber assay

\section{INVASION ASSAYS}

The cell invasion and metastasis were evaluated using the Matrigel invasion assay. Figure 5(a) illustrated the cell invasion images of treated and untreated cells after $24 \mathrm{~h}$ of treatment. Phase contrast microscopy images of untreated cells showed plenty of cells at the bottom of the Boyden chamber, while treated cells showed reduced invasion ability after $24 \mathrm{~h}$ of treatment, with a lesser number of cells observed at the bottom of the Boyden chamber. Treatment with recombinant D6 or DARC showed a negative impact on the invading ability of the cancer cells compared to the non-treated cells. The
Without treatment

a

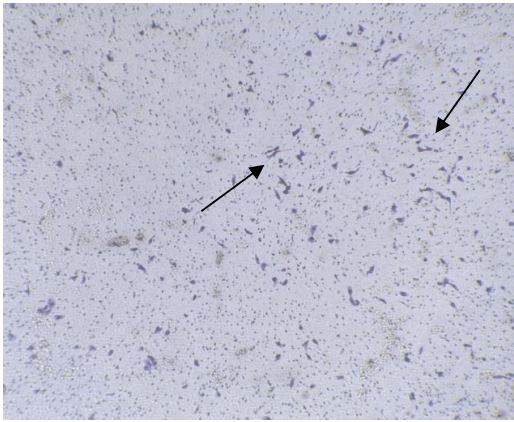

b

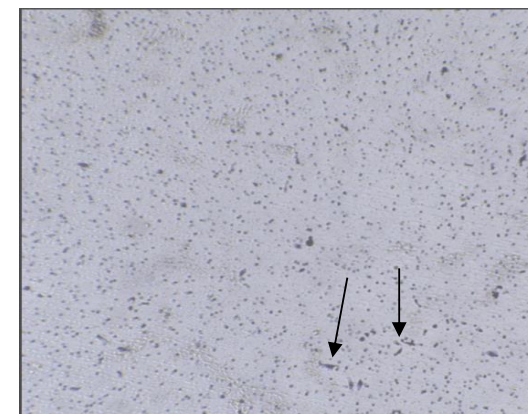

Invading cells are indicated by arrows
With treatment
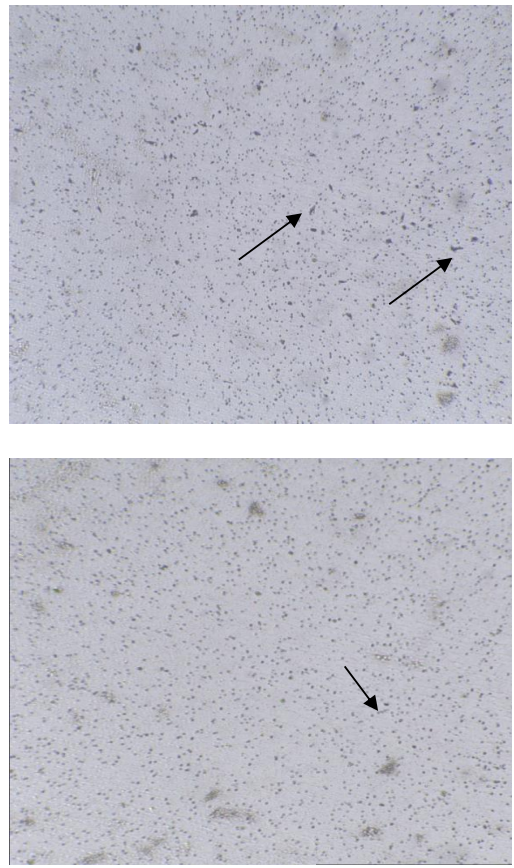

FIGURE 5(a). Cell invasion images images of (a) MDA-MB-231 \& (b) MCF-7 under phase contrast microscope $(400 \times$ magnification). Invading cells are indicated by arrows 


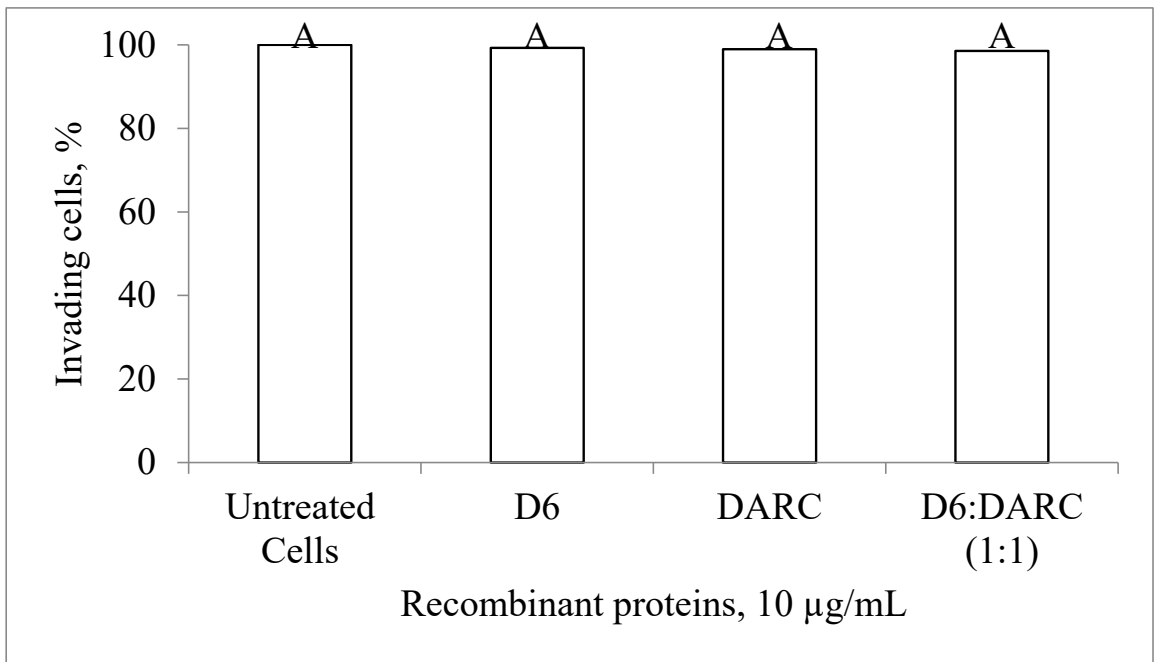

FIGURE 5(b). Effects of recombinant proteins on the invasiveness of MCF-7

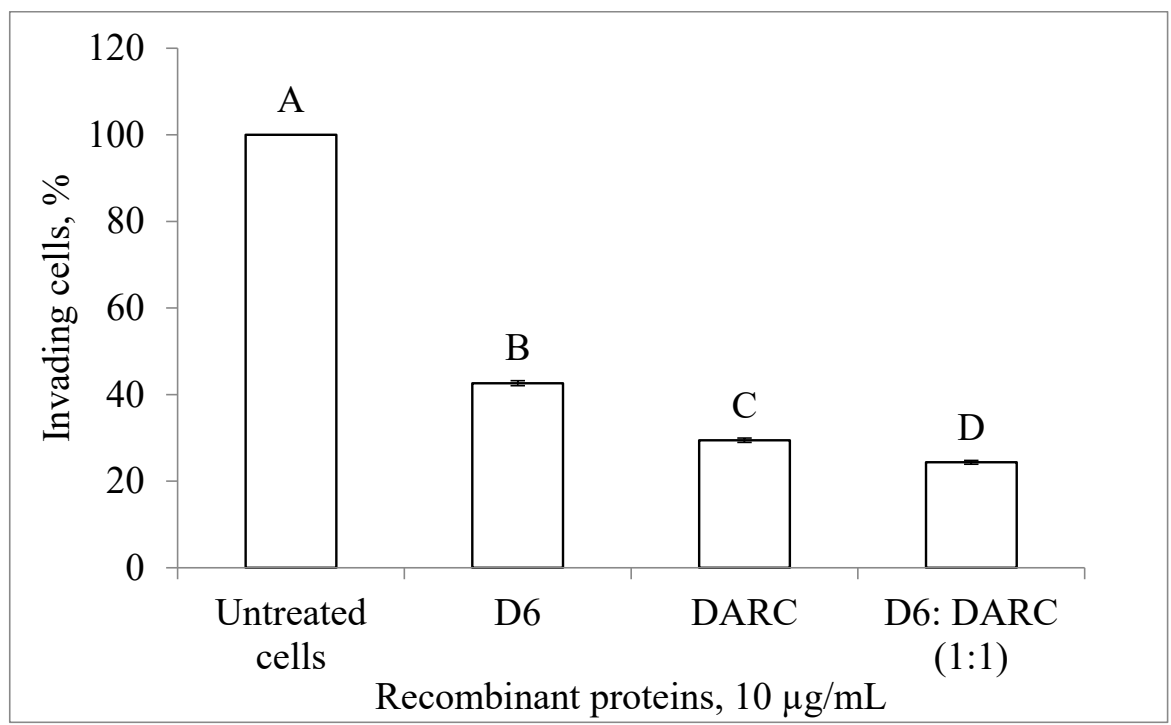

The experiment was carried out in triplicates, and the means that are significantly different are represented with different letters (Duncan, $p<0.05$ ). Capital letters indicate the means for the number of invading cells from MDAMB-231, whereas small letters indicate the means for the number of invading cells from MCF-7. Error bars indicate the standard deviation values of the triplicates.

FIGURE 5(c). Effects of recombinant proteins on the invasiveness of MDA-MB-231

impact of treatment was further justified by absorbance measurements. Invading assay conducted with $\mathrm{MCF}-7$ (Figure 5(b)) and MDA-MB-231 (Figure 5(c)) cells showed no significant difference among cells treated either with single recombinant protein or combination between two different types of recombinant proteins when compared to the untreated one. 


\section{DISCUSSION}

The bioactivity and functions of purified Pichiaexpressed recombinant D6 and DARC proteins were evaluated using in vitro cell-based assays to determine their effects on breast cancer cell migration and invasion. The wound healing assay performed to determine the role of recombinant D6 and DARC in cancer cell migration is an economical method. Apart from that, indirect ELISA was conducted to analyze the level of CCL2 in treated cells. The Boyden chamber-based assays were carried out to further investigate the influences of these recombinant proteins in cancer cell migration and invasion.

Prior to the migration and invasion studies, yeastexpressed recombinant D6 and DARC were tested on MDA-MB-231 and MCF-7 cells to determine their toxicity on the cells. The MTT analysis showed that the viability of MDA-MB-231 and MCF-7 cells was not significantly hampered by the presence of these recombinant proteins. The viability of these two breast cancer cell lines displayed a slightly decreasing trend with the increase in the concentration of the recombinant proteins. However, the reduction in viability was not significant compared to untreated cells, as it remained above $50 \%$ even after the addition of $100 \mu \mathrm{g} / \mathrm{mL}$ of recombinant proteins to the cells. The findings suggested that these recombinant decoy chemokine receptor proteins might not be involved in cancer cell death but act as silent receptors to inactivate the respective signaling pathways in breast cancer cells.

In cancer cells, there are numerous pathways leading to chemokine-induced cell migration and invasion, namely mitogen-activated protein kinase (MAPK), phosphatidylinositol 3-kinase (P13K), focal adhesion kinase (FAK), and Rho family of GTPases. However, the general mechanism of cancer cell migration and invasion is almost similar (Chen et al. 2020; Raman et al. 2011; Tan et al. 2006; Zhao et al. 2008). In experimental cell biology, migration is defined as the directed movement of cells on a substrate. It can occur on two-dimensional surfaces without any obstructive fiber network. On the other hand, invasion is defined as the movement of cells through a three-dimensional matrix, which is followed by the restructuring of the three-dimensional environment. During invasion, cells change their shape and interact with the extracellular matrix to travel through the matrix (Kramer et al. 2013). In previous studies, the transfer of cancer cells to specific organs by chemokines chemotaxis properties was observed (Ben-Baruch 2008; Rezaeeyan et al. 2018).

Wound healing or 'in vitro scratch assay' is popular in cell migration study as it is simple, versatile, technically non-demanding, and cost effective for the quantification of the alterations in cell migratory capacity due to experimental manipulations. This method allows the user to determine the migration ability of whole-cell masses. Besides the measurement of wound closure distance with time and comparing the readings to the control, it allows the user to observe specific migration changes or any impaired migratory phenotype that was previously unknown. It is a complex cellular and biochemical process needed for the restoration of the structurally damaged tissues. In the wound healing process, dynamic interactions and crosstalk between various cell types, interaction with extracellular matrix molecules, and the regulated production of soluble mediators and cytokines are involved (Grada et al. 2017). There are three phases in regulating wound healing, namely inflammation, proliferation, and remodeling (ZajaMilatovic \& Richmond 2008). Chemokines play a vital role in the wound healing process and were found to be involved in all three phases of the process (Raman et al. 2011). CCL2 is one of the chemokines that has been reported to improve the wound healing process by enhancing cell migration in studies conducted in-vitro with MCF-7 and MDA-MB-231 cells (Fang et al. 2012). CCL2 was also reported to promote wound healing after being induced by erythroid differentiation regulator 1 via MAP kinases in vitro and in vivo (Lee et al. 2020). It is one of the pro-inflammatory $\mathrm{CC}$ chemokines found in invasive and non-invasive breast cancer cells, and it was correlated with cancer cell migration and invasion $(\mathrm{Wu}$ et al. 2008). The controlled and specific expression of chemokine receptors plays a vital role in facilitating the characteristic patterns of cell migration and invasion, besides aiding in cell growth and cell survival (Slettenaar \& Wilson 2006). The binding of chemokine receptor to its ligand induces signal transduction, direct chemotaxis, and subsequently, promotes invasive responses in cancer cells. However, many recent studies have reported that the atypical action of chemokine receptors, in which the binding of these proteins to their respective ligands does not lead to a typical signaling pathway, neutralizes the action of chemokines and intercepts the respective pathways. The absence of the well-conserved DRYLAIVHA motif (DKYLEIVHA in ACKR2) has been assumed to explain the inability of atypical chemokine receptors in inducing downstream receptor signaling after ligand binding (Sjöberg et al. 2019). The D6 and DARC decoy chemokine receptors had been reported to inhibit the action of CCL2 (Galzi et al. 2010).

Concurring with the findings by Wang et al. (2006) and $\mathrm{Wu}$ et al. (2008) on the ability of D6 and DARC to inhibit the action of CCL2, our study showed that 
treating the cells with recombinant D6 and DARC reduced the effects of CCL2 in the cells, and thus, affected the recovery of wound or cell migration. The MCF-7 noninvasive breast cancer cells as background control were found to recover at $30 \mathrm{~h}$ of incubation after scratching. However, the introduction of recombinant D6 and DARC inhibited the migration of these cells, and a treatment dosage of $10 \mu \mathrm{g} / \mathrm{mL}$ appeared to reduce the migration of cells extensively. The wound gaps treated with $10 \mu \mathrm{g} /$ $\mathrm{mL}$ of recombinant proteins D6 and DARC remained more than $60 \%$ open at $30 \mathrm{~h}$ post-treatment compared to $0 \mathrm{~h}$. Besides comparing treated MDA-MB-231 cells with the non-treated one, the introduction of $10 \mu \mathrm{g} /$ $\mathrm{mL}$ recombinant D6 and DARC was also found to significantly influence wound healing compared to lower concentrations. Untreated MDA-MB-231 cells were found to have a more aggressive migration in which complete closure of wound gap was observed at $24 \mathrm{~h}$ post-treatment compared to the untreated MCF-7 cells, which closed at $30 \mathrm{~h}$ post-treatment. D6 or ACKR2 was reported to bind with only CC pro-inflammatory chemokines. The lack of a DRYLAIV motif made D6 a decoy chemokine receptor; thus, the binding of D6 with its ligand will neither elicit signal transduction nor activate a cascade of signaling pathway (Stone et al. 2017). In fact, D6 acts as a scavenger protein and rapidly internalizes and degrades its ligands. Thus, the addition of purified recombinant D6 will compete with the signaling chemokine receptors to bind pro-inflammatory $\mathrm{CC}$ chemokines that facilitate breast cancer cell migration and invasion. Upon binding, the CC chemokines were internalized and degraded, which explains the reduction in the level of CCL2 in the treated cells in ELISA. The decrease in CCL2 level and other pro-inflammatory $\mathrm{CC}$ chemokines in the cells resulted in the reduction in the number of migrating and invading cells. Wu et al. (2008) had demonstrated that the overexpression of D6 in human breast cancer cells inhibited the proliferation and invasion of cells. This inhibition was associated with a reduction in chemokines, vessel density, and tumor-associated macrophage (TAM) infiltration. D6 inhibited tumor growth, metastasis, angiogenesis, and infiltration of TAMs by reducing the expression of chemokines.

On the other hand, the lack of a DRY motif made DARC another member of the decoy chemokine receptors. The binding of DARC with its ligand silences the action of the respective chemokine (Hansell et al. 2011). Similar to D6, the introduction of purified recombinant DARC silences the actions of CCL2 in cancer cells upon ligand-receptor binding, which explains the reduction of CCL2 level in ELISA. Nevertheless, different from D6, DARC binds both pro-inflammatory CC and CXC chemokines. Comparing the two recombinant proteins, recombinant DARC was observed to be more effective in inhibiting cell migration than recombinant D6 in MDA-MB-231 cells. The wound gap was observed to close completely at $30 \mathrm{~h}$ post-treatment with recombinant D6 but remained visible with recombinant DARC. The ability of DARC to bind and silence more than one category of pro-inflammatory chemokines in cancer cells well explains the differences observed between cells treated with D6 and those treated with DARC. As more pro-inflammatory chemokines were silenced, both chemotaxis and cell invasion were effectively downregulated. This explains why cells treated with DARC showed a bigger wound area, lower CCL2 level, and lower migrating and invading cell numbers in cellbased assays compared to cells treated with D6. Wang et al. (2006) showed that low DARC protein expression is associated with estrogen-receptor (ER) status, lymph node metastases (LNM), tumor multivessel density (MVD), distant metastasis, and reduced survival in human breast cancer samples. DARC overexpression inhibited tumorigenesis and metastasis, possibly by interfering with tumor angiogenesis. As previously mentioned, D6 binds $\mathrm{CC}$ chemokines and DARC binds $\mathrm{CC}$ and $\mathrm{CXC}$ chemokines. Hence, the combinatory use of D6 and DARC increased the competitive level of ligand binding among signaling receptor proteins and recombinant proteins to their respective ligands in the cancer cells' microenvironment. In the study with recombinant D6 and DARC combination, wound healing results showed that the combination of the two recombinant proteins at a ratio of 1:1 significantly affected wound recovery compared to the use of a single recombinant protein. Yu et al. (2015) reported a strong association between the co-expression of both DARC and D6 and relapse-free survival (RFS) in breast cancer patients. Their findings also implied that the chemokine decoy receptors might affect disease progression by influencing the tumor microenvironment but not the cancer cells directly.

Meanwhile, ELISA results showed a remarkable reduction of CCL2 level in treated invasive and noninvasive breast cancer cells, indicating a negative association between recombinant D6 or DARC with their ligands. The CCL2 level of the treated cells was found to decrease with an increase in recombinant D6 or DARC dosage. A drastic reduction in CCL2 level was observed in the cells treated with $10 \mu \mathrm{g} / \mathrm{mL}$ of recombinant D6 or DARC. The combination of recombinant D6 and DARC at a ratio of 1:1 effectively reduced CCL2 level in cancer cells and was more promising compared to treatment with a single recombinant protein. The combination of 
D6 and DARC allowed the binding of more than one category of chemokine. Both pro-inflammatory $\mathrm{CC}$ and CXC chemokines can be 'captured' by the combination of recombinant decoy proteins. As recombinant D6 and DARC complemented each other in binding with their ligands, more pro-inflammatory chemokines were degraded or silenced. This caused an effective downregulation in signal transduction in cancer cells, and subsequently, reduced the number of migrating and invading cells. The quantitative ELISA results complemented the results from wound healing assays, which qualitatively suggested the negative effects of recombinant D6 or DARC on the migration of breast cancer cells. The role of these recombinant proteins in inhibiting cancer cell mobility was shown to be associated with the downregulation of CCL2 level in the cells. Other than CCL2, other chemokines are reported to be involved in cancer cells' migration and invasion, such as CCL5 and interleukin 6. Among pro-inflammatory $\mathrm{CC}$ and $\mathrm{CXC}$ chemokines, CXCL1, CXCL2, and CXCL3 were reported to be stimulated by CXCR2 receptor to stimulate the growth of melanoma cells (Dhawan \& Richmond 2002). In breast cancer cells, other than CCL2, CXCL12 was another popular chemokine, which is reportedly involved in breast cancer cell metastasis. Upregulation of CXCR4, the receptor of CXCL12, was found to enhance breast cancer cells migration and invasion, which subsequently promoted lymph node metastasis (Allinen et al. 2004; Cabioglu et al. 2005). Fibroblast-derived CXCL14 was found to be involved in epithelial-to-mesenchymal transition (EMT) and metastasis of breast cancer cells. ACKR2 (D6) was identified as a critical mediator of CXCL14-induced signaling, although no direct interaction between CXCL14 and ACKR 2 could be found (Sjöberg et al. 2019). Wang et al. (2006) investigated the tumorigenesis effects of DARC on MDA-MB-231 and MDA-MB-435HM breast cancer cells, which have a high capacity of spontaneous pulmonary metastasis, by transfecting these cells with a DARC expression vector using lipofectamine. Results showed that DARC overexpression led to tumorigenesis and/or metastasis inhibition, which was associated with reduced CCL2 levels. It was also associated with the expression of matrix metallopeptidase 9 (MMP-9) and tumor multivessel density (MVD) in xenograft tumors. The results showed that DARC overexpression inhibited tumorigenesis and metastasis of breast cancer, possibly via inhibition of angiogenic chemokines and subsequent sequestration of tumor neovascularity.

Malignant cancer cells invade and metastasize to nearby cells and tissues. Given the impact of yeastexpressed recombinant proteins D6 and DARC on cell migration (via wound healing assays) and CCL2 level in MDA-MB-231 and MCF-7 cells, further investigations were carried out to study the effects of these recombinant proteins on cell migration and invasion via Boyden chamber assay. Basically, the setup of transwell invasion assay is the same as transwell migration assay; the only difference is the coating of extracellular matrix (ECM) on the porous membrane of the insert. The purpose of coating ECM is to block the cells from migrating through the porous membrane to the lower chamber. Only cells which possess invasion ability will be able to invade ECM and migrate through the porous membrane. In this study, the transwell chamber, which was coated with Matrigel, was used to study breast cancer cell invasion. Matrigel is a type of gelatinous protein mixture that has been broadly used to simulate the ECM in vitro (Valle Oseguera \& Spencer 2017). Matrigel transwells mimic extracellular matrix and enable the user to study the invasion of cancer cells. Membrane pore size is crucial for the active transmigration of cells in a transwell assay. Pore size should be smaller than the cell diameter to prevent unspecific dropping of cells from the upper chamber to the lower chamber. In this study, insert with a membrane pore size of $8 \mu \mathrm{m}$ was used as it is suitable for MDAMB-231 and MCF-7 cells. The Boyden chamber helps in analyzing the ability of single cells to directionally respond to the available chemoattractant. The growth medium in the upper chamber was serum-free, while the growth medium in the lower chamber contained FBS as the chemoattractant. The presence of chemoattractant in the lower chamber induced the migration of cells from the upper chamber towards the lower chamber. Cells migrate in the vertical direction through membrane pores and get attached to the bottom of the insert. Transwell migration assay differs from the qualitative wound healing assay and allows the migrated cells to be analyzed quantitatively. This makes the analysis more reliable, and it can be used to complement the results of wound healing assays. Besides, the availability of different cell culture inserts and sizes, as well as the ease of experimental setup, make transwell assay relatively useful.

Cell migration quantified in transwell assays showed that the combination of recombinant D6 and DARC at a ratio of $1: 1(10 \mu \mathrm{g} / \mathrm{mL})$ significantly affected the mobility of MDA-MB-231 as well as MCF-7 cells compared to cells treated with a single type of recombinant protein (recombinant D6 or DARC). These observations suggested that D6 and DARC complement each other in inhibiting the migration of cells. This finding is similar to the results obtained from wound healing assay and is in agreement with ELISA results where CCL2 levels in the treated 
cells were quantified. Invasion assay using Boyden chamber pre-coated with Matrigel demonstrated that the yeast-expressed recombinant D6 and DARC have negative effects on the invasion ability of breast cancer cells. Similar to the findings from wound healing assays, ELISA (CCL2 levels), and migration assays using Boyden chamber, invasion assays showed that the combination of recombinant D6: DARC at the ratio of 1: $1(10 \mu \mathrm{g} /$ $\mathrm{mL}$ ) had the most significant impact on the invasion and metastasis ability of MDA-MB-231 and MCF-7 cells. Different from wound healing assay, instead of merely reporting about the negative effects of recombinant proteins on cell mobility, transwell invasion assay showed cell chemotaxis, or in other words, the directional movement of cells towards a chemoattractant (Justus et al. 2014). Thus, the current findings also showed that Pichia-expressed recombinant D6 and DARC decreased the chemotaxis ability of breast cancer cells. Quantitative results obtained from invasion assays justified and further confirmed the effects of Pichia-expressed recombinant D6 and DARC in inhibiting breast cancer cell migration and invasion. Invasion assay performed on MCF-7 cells showed no significant difference in invading cell numbers between treated and untreated cells. MCF-7 is a noninvasive breast cancer cell line, and the cells remained at the upper chamber of the transwell because of their inability to invade. In other words, the cells were blocked by the Matrigel and could not pass through the porous membrane of the insert.

Taken together, findings from all the assays conducted in this study suggested that purified Pichiaexpressed recombinant D6 and DARC are bioactive and functional. The role of these recombinant proteins in decreasing CCL2 level and inhibiting the migration and invasion of breast cancer cells was well observed in the present study. The primary chemokine decoy receptors, D6 and DARC, confer their inhibitory effects on breast cancer cell proliferation and invasion mostly via the sequestration of pro-malignant chemokines (Yang et al. 2013; Yu et al. 2015). Other than being expressed in cancer cells, these chemokine decoy receptors were also present in blood and/or lymphatic endothelial cells and erythrocytes in the circulation. Hematogenous and lymphatic distribution are the two routes for breast cancer metastasis, and thus, chemokine decoy receptors also serve as a systemic barrier against such metastasis ( $\mathrm{Yu}$ et al. 2015).

\section{CONCLUSION}

In summary, the use of purified Pichia-expressed recombinant D6 and DARC was observed to be capable of affecting cell migration, reducing CCL2 level, and inhibiting chemotaxis and invasion of breast cancer cells, as shown by wound healing assay, ELISA, and Boyden chamber-based migration and Matrigel invasion assay. The effects were found to be concentration-dependent. Since there was no previous study on the combinatorial effects of the two decoy proteins, our study proved to be interesting and vital in throwing some light on this aspect. The results showed that the combination of two different types of purified recombinant proteins had extensive negative effects on CCL2 level, cancer cell migration, and invasion compared to single proteins tested at the same concentration. This is the first in vitro study to report about the combinatory use of two different types of recombinant decoy chemokine receptor proteins in downregulating breast cancer cell migration and invasion. This study provides useful information about the effects of D6 and DARC on tumorigenesis and the metastatic potential of breast cancer cells and may lead to novel therapeutic strategies against breast cancer in the future.

\section{ACKNOWLEDGEMENTS}

The authors would like to express their gratitude to Universiti Sains Malaysia for Research University Grant (RUI Grant No: 1001/CIPPM/8012377). The first author is grateful to the Ministry of Science, Technology and Innovation (MOSTI) for National Science Fellowship awarded during the study. The authors declare that there is no conflict of interest regarding the publication of this article.

\section{REFERENCES}

Ahmad, F.K., Deris, S. \& Abdullah, M.S. 2011. Synergy network based inference for breast cancer metastasis. Procedia Computer Science 3: 1094-1100.

Allinen, M., Beroukhim, R., Cai, L., Brennan, C., Lahti-Domenici, J., Huang, H., Porter, D., Hu, M., Chin, L., Richardson, A., Schnitt, S., Sellers, W.R. \& Polyak, K. 2004. Molecular characterization of the tumor microenvironment in breast cancer. Cancer Cell 6(1): 17-32.

Ben-Baruch, A. 2008. Organ selectivity in metastasis: Regulation by chemokines and their receptors. Clinical \& Experimental Metastasis 25(4): 345-356.

Bray, F., Ferlay, J., Soerjomataram, I., Siegel, R.L., Torre, L.A. \& Jemal, A. 2018. Global cancer statistics 2018: GLOBOCAN estimates of incidence and mortality worldwide for 36 cancers in 185 countries. CA: A Cancer Journal for Clinicians 68(6): 394-424.

Cabioglu, N., Sahin, A.A., Morandi, P., Meric-Bernstam, F., Islam, R., Lin, H.Y., Bucana, C.D., Gonzalez-Angulo, A.M., Hortobagyi, G.N. \& Cristofanilli, M. 2009. Chemokine receptors in advanced breast cancer: Differential 
expression in metastatic disease sites with diagnostic and therapeutic implications. Annals of Oncology 20(6): 10131019.

Cabioglu, N., Yazici, M.S., Arun, B., Broglio, K.R., Hortobagyi, G.N., Price, J.E. \& Sahin, A. 2005. CCR7 and CXCR4 as novel biomarkers predicting axillary lymph node metastasis in T1 breast cancer. Clinical Cancer Research 11(16): 5686-5693.

Chen, L., Zhang, S., Shen, Y., Qi, L., Zhang, Z., Tian, H. \& Zou, Z. 2020. Thymus-expressed chemokine secreted by breast cancer cells promotes metastasis and inhibits apoptosis. Oncology Reports 43: 1875-188.

Dhawan, P. \& Richmond, A. 2002. Role of CXCL1 in tumorigenesis of melanoma. Journal of Leukocyte Biology 72(1): 9-18.

Fang, W.B., Jokar, I., Zou, A., Lambert, D., Dendukuri, P. \& Cheng, N. 2012. CCL2/CCR2 chemokine signaling coordinates survival and motility of breast cancer cells through Smad3 protein- and p42/44 mitogen-activated protein kinase (MAPK)-dependent mechanisms. Journal of Biological Chemistry 287(43): 36593-36608.

Galzi, J.L., Hachet-Haas, M., Bonnet, D., Daubeuf, F., Lecat, S., Hibert, M., Haiech, J. \& Frossard, N. 2010. Neutralizing endogenous chemokines with small molecules: Principles and potential therapeutic applications. Pharmacology \& Therapeutics 126(1): 39-55.

Gencer, S., van der Vorst, E., Aslani, M., Weber, C., Döring, Y. \& Duchene, J. 2019. Atypical chemokine receptors in cardiovascular disease. Thrombosis and Haemostasis 119(4): 534-541.

Grada, A., Otero-Vinas, M., Prieto-Castrillo, F., Obagi, Z. \& Falanga, V. 2017. Research techniques made simple: Analysis of collective cell migration using the wound healing assay. The Journal of Investigative Dermatology 137(2): e11-e16.

Graham, G.J. 2009. D6 and the atypical chemokine receptor family: Novel regulators of immune and inflammatory processes. European Journal of Immunology 39(2): 342351.

Hansell, C.A., Hurson, C.E. \& Nibbs, R.J. 2011. DARC and D6: Silent partners in chemokine regulation? Immunology and Cell Biology 89(2): 197-206.

Hansell, C.A., Simpson, C.V. \& Nibbs, R.J. 2006. Chemokine sequestration by atypical chemokine receptors. Biochemical Society Transactions 34(6): 1009-1013.

Justus, C.R., Leffler, N., Ruiz-Echevarria, M. \& Yang, L.V. 2014. In vitro cell migration and invasion assays. Journal of Visualized Experiments 88: 51046.

Kramer, N., Walzl, A., Unger, C., Rosner, M., Krupitza, G., Hengstschlager, M. \& Dolznig, H. 2013. In vitro cell migration and invasion assays. Mutation Research 752(1): 10-24.

Lee, B.C., Song, J., Lee, A., Cho, D. \& Kim, T.S. 2020. Erythroid differentiation regulator 1 promotes wound healing by inducing the production of $\mathrm{C}-\mathrm{C}$ motif chemokine ligand
2 via the activation of MAP kinases in vitro and in vivo. International Journal of Molecular Medicine 46(6): 21852193.

Lokeshwar, B.L., Kallifatidis, G. \& Hoy, J.J. 2020. Atypical chemokine receptors in tumor cell growth and metastasis. Advances in Cancer Research 145: 1-27.

Mantovani, A., Bonecchi, R. \& Locati, M. 2006. Tuning inflammation and immunity by chemokine sequestration: Decoys and more. Nature Reviews Immunology 6(12): 907-918.

Maryam, M., Samaneh, R., Amin, J., Seyed, H.A., Hossein, M.O., Tannaz, J. \& Amirhossein, S. 2020. Peptide decoys: A new technology offering therapeutic opportunities for breast cancer. Drug Discovery Today 25(3): 593-598.

Raman, D., Sobolik-Delmaire, T. \& Richmond, A. 2011. Chemokines in health and disease. Experimental Cell Research 317(5): 575-589.

Rezaeeyan, H., Shirzad, R., McKee, T.D. \& Saki, N. 2018. Role of chemokines in metastatic niche: New insights along with a diagnostic and prognostic approach. APMIS: Acta Pathologica, Microbiologica, et Immunologica Scandinavica 126(5): 359-370.

Saçmac1, H. \& Özcan, S. 2020. A critical role for expression of atypical chemokine receptor 2 in multiple sclerosis: A preliminary project. Multiple Sclerosis and Related Disorders 38: 101524

Sandhu, R., Parker, J.S., Jones, W.D., Livasy, C.A. \& Coleman, W.B. 2010. Microarray-based gene expression profiling for molecular classification of breast cancer and identification of new targets for therapy. Laboratory Medicine 41(6): 364-372.

Sjöberg, E., Meyrath, M., Milde, L., Herrera, M., Lövrot, J., Hägerstrand, D., Frings, O., Bartish, M., Rolny, C., Sonnhammer, E., Chevigné, A., Augsten, M. \& Östman, A. 2019. A novel ACKR2-dependent role of fibroblastderived CXCL14 in epithelial-to-mesenchymal transition and metastasis of breast cancer. Clinical Cancer Research: An Official Journal of the American Association for Cancer Research 25(12): 3702-3717.

Slettenaar, V.I.F. \& Wilson, J.L. 2006. The chemokine network: A target in cancer biology? Advanced Drug Delivery Reviews 58(8): 962-974.

Stone, M.J., Hayward, J.A., Huang, C., Huma, Z.E. \& Sanchez, J. 2017. Mechanisms of regulation of the chemokinereceptor network. International Journal of Molecular Sciences 18(2): 342

Tan, W., Martin, D. \& Gutkind, J.S. 2006. The Galpha13-Rho signaling axis is required for SDF-1-induced migration through CXCR4. Journal of Biological Chemistry 281(51): 39542-39549

Vacchini, A., Cancellieri, C., Milanesi, S., Badanai, S., Savino, B., Bifari, F., Locati, M., Bonecchi, R. \& Borroni, E.M. 2020 Control of cytoskeletal dynamics by $\beta$-arrestin $1 /$ myosin $\mathrm{Vb}$ signaling regulates endosomal sorting and scavenging activity of the atypical chemokine receptor ACKR2. Vaccines 8(3): 542 
Valle Oseguera, C.A. \& Spencer, J.V. 2017. Human cytomegalovirus interleukin-10 enhances matrigel invasion of MDA-MB-231 breast cancer cells. Cancer Cell International 17(1): 24.

Wang, J., Ou, Z.L., Hou, Y.F., Luo, J.M., Shen, Z.Z., Ding, J. \& Shao, Z.M. 2006. Enhanced expression of Duffy antigen receptor for chemokines by breast cancer cells attenuates growth and metastasis potential. Oncogene 25(54): 72017211.

Wilson, G.J., Fukuoka, A., Love, S.R., Kim, J., Pingen, M., Hayes, A.J. \& Graham, G.J. 2020. Chemokine receptors coordinately regulate macrophage dynamics and mammary gland development. Development 147(12): dev187815.

Wu, F.Y., Ou, Z.L., Feng, L.Y., Luo, J.M., Wang, L.P., Shen, Z.Z. \& Shao, Z.M. 2008. Chemokine decoy receptor D6 plays a negative role in human breast cancer. Molecular Cancer Research 6(8): 1276-1288.

Yang, C., Yu, K.D., Xu, W.H., Chen A.X., Fan, L., Ou, Z.L. \& Shao, Z.M. 2013. Effect of genetic variants in two chemokine decoy receptor genes, DARC and CCBP2, on metastatic potential of breast cancer. PLOS ONE 8: e78901.
Yu, K.D., Wang, X., Yang, C., Zeng, X.H. \& Shao, Z.M. 2015. Host genotype and tumor phenotype of chemokine decoy receptors integrally affect breast cancer relapse. Oncotarget 6(28): 26519-26527.

Zaja-Milatovic, S. \& Richmond, A. 2008. CXC chemokines and their receptors: A case for a significant biological role in cutaneous wound healing. Histology and Histopathology 23(11): 1399-1407.

Zhao, M., Mueller, B.M., DiScipio, R.G. \& Schraufstatter, I.U. 2008. Akt plays an important role in breast cancer cell chemotaxis to CXCL12. Breast Cancer Research and Treatment 110(2): 211-222.

Institute for Research in Molecular Medicine (INFORMM)

Universiti Sains Malaysia

11800 USM, Penang

Malaysia

*Corresponding author; email: chew@usm.my

Received: 6 August 2020

Accepted: 19 February 2021 